\title{
LEGISLAÇÃO URBANÍSTICA E FORMA URBANA. SÃO PAULO NO SÉCULO XXI
}

\author{
Tatiane Oliveira Teles \\ Universidade de São Paulo, Faculdade de Arquitetura e Urbanismo, São Paulo, SP, Brasil.
}

\begin{abstract}
Resumo
A Lei Geral de Zoneamento de 1972 marcou a produção da tipologia do edifício isolado no lote, obstando a relação contínua entre edifício e cidade. Tal morfologia, considerada deletéria à dinâmica urbana, perdurou por meio de legislações urbanísticas até 2014, quando se promulgou o Plano Diretor Estratégico; dois anos mais tarde, em 2016, foi a vez da Lei de Parcelamento, Uso e Ocupação do Solo. Tais leis implementaram incentivos à fachada ativa, diretriz que prefigura contestações à tipologia do edifício isolado no lote. Visto isso, analisa-se em que medida a estratégia da fachada ativa é um avanço no tocante aos objetivos dessas leis (SÃO PAULO (Município), 2014, p. 54; 2016, p. 23), de configurar espaços urbanos que, embora atrelados à unidade do lote, tenham como referência a composição da quadra, superando a degeneração da forma urbana e garantindo uma relação melhor entre os espaços públicos e privados.

Palavras-chave Cidade de São Paulo; Legislações Urbanísticas; Forma Urbana; Edifício Isolado no Lote, Fachada Ativa.
\end{abstract}




\title{
ARTICLES
}

PLANNING AND PUBLIC POLICY

\section{URBAN REGULATION AND URBAN FORM. SÃO PAULO IN THE $21^{\text {ST }}$ CENTURY}

\author{
Tatiane Oliveira Teles \\ Universidade de São Paulo, Faculdade de Arquitetura e Urbanismo, São Paulo, SP, Brazil.
}

\begin{abstract}
The 1972 General Zoning Law marked the production of the freestanding building type, preventing the continuous connexion between building and city. Such morphology, considered harmful to urban dynamics, lasted through urban legislation until 2014, when it was enacted the Strategic Master Plan and two years later, in 2016, the Land Installment, Use and Occupation Law. These laws implemented incentives for the active façade, a guideline that prefigures objection to the typology of the freestanding building. As such, it is analyzed to what extent the strategy of the active façade is an advance in terms of the strategy of these laws objectives (SÃO PAULO (Município), 2014, p. 54; 2016, p. 23), configurating urban spaces which, although connected to the lot unit, have as reference the block composition, overcoming the urban form degeneration and ensuring a better relation between public and private spaces.

Keywords

São Paulo City; Urban Planning Regulations; Urban form; Freestanding Building Active Façade.
\end{abstract}




\section{LEGISLAÇÃO URBANÍSTICA E FORMA URBANA. SÃO PAULO NO SÉCULO XXI}

Tatiane Oliveira Teles

Introdução

Este artigo objetiva aprofundar a análise da relação entre espaços públicos e privados, com ênfase na que é mantida entre as legislações urbanísticas e seus resultados morfológicos, em que elementos arquitetônicos são entendidos como unidades que compõem física e socialmente a cidade. Segundo essa interpretação, o Plano Diretor Estratégico (PDE), de 2014, e sua Lei complementar de Parcelamento, Uso e Ocupação do Solo (LPUOS), de 2016, implementaram estratégias qualificadoras da ocupação do solo, consideradas formatadores de um novo paradigma na produção espacial.

Visto isso, esta pesquisa analisa em que medida a forma do objeto arquitetônico, condicionada pelos parâmetros legais que induzem a "fachada ativa”, pode ser vista como um avanço ou não no tocante à estratégia da LPUOS de 2016 em garantir “[...] qualidade na relação entre os espaços públicos e privados (SÃO PAULO (Município), 2016, p. 23) e ao objetivo do artigo 27 do PDE de 2014, de “[...] proporcionar a composição de conjuntos urbanos que superem exclusivamente o lote como unidade de referência da configuração urbana, sendo também adotada a quadra como referência de composição do sistema edificado" (SÃO PAULO (Município), 2014, p. 54).

\footnotetext{
1. O presente artigo é parte da pesquisa de mestrado intitulada Legislação urbanística e forma urbana. São Paulo, século XXI, desenvolvida na Faculdade de Arquitetura e Urbanismo da Universidade de São Paulo (FAU-USP) e orientada por Luiz Antonio Recamán Barros. Foi realizada com o apoio da Coordenação de Aperfeiçoamento de Pessoal de Nível Superior - Brasil (Capes), Código de Financiamento o01, no período de 1 de abril de 2018 a 1 de dezembro de 2019, e da Fundação de Amparo à Pesquisa do Estado de São Paulo (Fapesp), no período de 1 de janeiro de 2019 a 31 de março de 2020.
} 
A perspectiva aqui adotada baseia-se na compreensão inserida na Constituição Federal de 1988, e reiterada em 2001, no Estatuto da Cidade (BRASIL, 2001), de que o direito de construir é separado do direito à propriedade, condicionando este último a deveres para com a coletividade. Essa lógica, que fundamenta a "função social da propriedade" (ANTENOR, 2001, p. 213) e o "potencial construtivo adicional” por meio da Outorga Onerosa do Direito de Construir (GUERRA, 1981, p. 75), é norteadora desta pesquisa, que busca explicitar que essa compreensão deveria ser igualmente aplicada à forma urbana, dado que o conjunto edificado, ainda limitado ao lote, também impacta o espaço coletivo.

Com isso, a pesquisa ora apresentada pretende contribuir para o conjunto de trabalhos que reconhecem as legislações urbanísticas como elementos que conferem à esfera municipal a mediação do conflito entre o espaço privado e o espaço público. Trata-se de uma oportunidade de elaborar uma posição crítica à degeneração da forma urbana resultante da lógica econômica prevalente na produção de seu espaço.

\section{Revisão bibliográfica}

Dentre as pautas recentes da arquitetura e urbanismo, sobretudo após a aprovação do Estatuto da Cidade $^{2}$, que consiste em uma lei federal de política urbana, destaca-se o papel determinante das legislações urbanísticas como instrumentos de orientação e mediação dos mais diversos fatores que incidem sobre a produção do espaço urbano (FERREIRA; MARICATO, 2001; NOBRE, 2006; ROSSBACH, 2016; MONTANDON, 2016).

Embora essa pauta ainda esteja em voga, nota-se um predomínio histórico no município de São Paulo no que se refere ao engajamento para aperfeiçoar os Planos Diretores 3 , sem, contudo, haver mobilização similar ao que concerne ao desenho urbano, normatizado sobretudo pelas leis complementares de Parcelamento, Uso e Ocupação do Solo4. Estas, por sua vez, incentivaram o tipo de edifício isolado no lote e, de 1972 até 2014, apresentaram características, que continuam

\footnotetext{
2. Em 1988, foram inseridos na Constituição Federal os artigos 182 e 183, que consolidaram a aplicação da função social na propriedade rural e urbana. Foram regulamentados após treze anos, em 2001, com a promulgação do Estatuto da Cidade (BRASIL, 2001), cuja operatividade é atrelada à elaboração de um Plano Diretor Municipal.

3. Leis municipais que orientam o crescimento e o desenvolvimento urbano de todo o município, conforme 0 art. 40 do Estatuto da Cidade.

4. Leis que estabelecem normas complementares ao Plano Diretor Estratégico, que dispõem sobre parcelamento, uso e ocupação do solo do município de São Paulo.
} 
vigentes, consideradas deletérias do ponto de vista da morfologia urbana ${ }^{5}$ (NAKANO; GUATELLA, 2015, p. 146). O diagnóstico apresentado é resultado de uma conjuntura de planejamento da cidade que reinterpreta o "zoning norte-americano"6 e que incorpora pressupostos da vanguarda do movimento moderno, como a organização setorizada das funções urbanas, a autonomia dos edifícios pautados pela busca de garantias mínimas de ventilação e iluminação, assim como a negação da rua pré-industrial, entendida como um entrave às novas velocidades dos automóveis (PORTZAMPARC, 1997, p. 39).

O arquiteto e urbanista francês Portzamparc (apud NOTO, 2017, p. 102) advoga que tais pressupostos modernistas esfacelaram a morfologia urbana da quadra de ocupação perimetral. De acordo com ele:

A ruptura descrita pelo autor [PORTZAMPARC, 1997] é dramática. A lógica milenar de construção da cidade a partir da distinção entre cheios e vazios é subvertida pela possibilidade de multiplicação dos vazios e de concentração (em altura) dos cheios. A esta equação, foi adicionado o fator automóvel[,] que também desviou o foco do urbanismo para a possibilidade de um funcionamento dos sistemas de deslocamento intraurbano de outra ordem. O quarteirão perdeu a raiz de sua necessidade: a rua não seria mais o único lugar do pedestre, uma vez que as distâncias a serem percorridas passam a contar com o auxílio da mecanização. Os espaços públicos puderam, assim, multiplicar-se em dimensão e frequência.

Essa subversão da lógica de cheios e vazios da quadra tradicional é reconhecível nos esquemas ilustrativos feitos por Ernst May (Figura 1) sobre a evolução da quadra, publicados na revista Das neue Frankfurt, em 1930. Como revela Noto (2017, p. 99):

[...] se o edifício deve ser explorado em suas melhores condições de desempenho (ambiental, estrutural, ocupacional), não deve se submeter a premissas alheias a sua lógica particular. [...] 0 diagrama da evolução da cidade, apresentado por May (1930)[,] é a perfeita ilustração do desmonte gradativo da ocupação das quadras. Do quartei-

\footnotetext{
5. Segundo Talen: "[...] urban morphology [...] is the study of physical urban form and the people and the processes that shape it” [[...] morfologia urbana [...] é o estudo da forma física urbana e das pessoas e processos que a conformam (tradução nossa)]. TALEN, E. City rules: how regulations affect urban form. London: Island Press, 2012. p. 17-18.

6. Para Feldman (2005, p. 114), o zoning norte-americano, cujas características técnicas coincidiam com o urbanismo moderno, pautava-se em uma preocupação programática e em uma negligência com a forma urbana; ele serviu de referência desde o início do século XX para debates e proposições dos mais diversos engenheiros e urbanistas radicados em São Paulo, tais como Francisco Prestes Maia, Anhaia Melo, Victor da Silva Freire, João Florence de Ulhoa Cintra, Carlos Lodi, entre outros.
} 
rão de ocupação perimetral, com lotes múltiplos respeitando uma lógica implícita de alinhamentos com a criação de espaços internos ambíguos e aleatórios à rigidez funcionalista dos blocos paralelos perfeitamente orientados e igualmente espaçados.

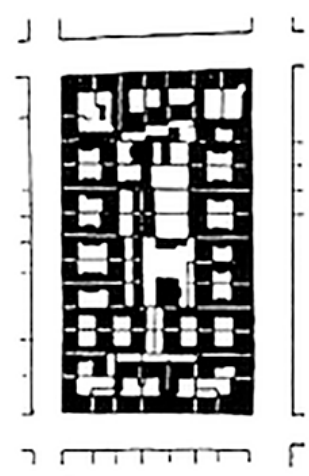

I.

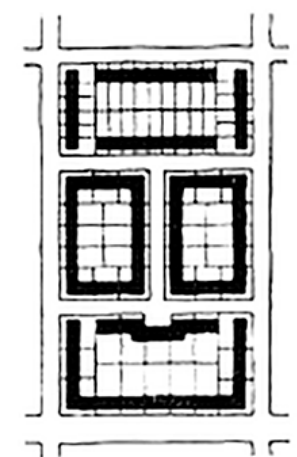

II.

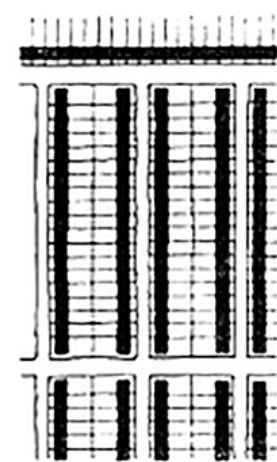

III.

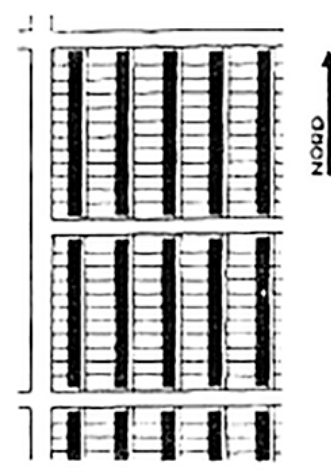

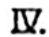

Figura 1. Esquemas ilustrativos, por Ernst May, da evolução da quadra. Fonte: Panerai; Castex; Depaule (2013, p. 117).

No Brasil, de acordo com manifestações de diversos autores (CHUVA, 2003; WISNIK, 2004; ZEIN, 2005), o urbanismo e a arquitetura moderna tornaram-se parte da cultura nacional. Mesmo sem possuir as “[...] condições socioprodutivas que catalisaram a formulação daquela arquitetura no cenário centro-europeu [...]” (NOTO, 2017, p. 39), o país destacou-se no âmbito internacional pela interpretação da modernidade correlacionada à tradição cultural ${ }^{7}$. E, assim como outros países da América Latina, a aclamação do movimento moderno resultou na sua permanência, ao perpassar diversos regimes políticos.

A despeito da proposta modernista socializante, de ambiguidade entre edifício e cidade, da cidade no parque, de prédios sobre pilotis, da diluição dos limites entre interior e exterior, a apropriação dessas normativas por uma sociedade de características sociais segregadoras as imprimiu também no território. No texto intitulado "Enclaves fortificados: a nova segregação urbana" presente em sua obra Cidade de muros, Teresa Caldeira relaciona a reinterpretação da sintaxe moderna com estratégias de segregação. Afirma essa autora: “[...] os elementos mantidos são aqueles que destroem o espaço público e a vida social moderna [...] os elementos modificados ou abandonados são os que pretendem criar igualdade” (1997, p. 169).

7. Sobretudo após a publicação do catálogo e a exposição Brazil builds: architecture new and old, 1652-1942, organizada pelo Museu de Arte Moderna de Nova York, em 1943, realizada pelo arquiteto estadunidense Philip L. Goodwin e baseada em fotografias feitas por G. E. Kidder Smith. 
Sob perspectiva similar, Ermínia Maricato, em Planejamento urbano no Brasil: as ideias fora do lugar e o lugar fora das ideias (2000), faz críticas ao urbanismo modernista, fundamentalmente em relação à fragmentação dos espaços e à negação da rua:

[...] a segregação espacial e a ordem rígida decorrentes do urbanismo modernista mereceram muitas críticas que não vieram apenas de setores neoliberais. Jane Jacobs formulou sua crítica, ainda nos anos [19]6o afirmando que o caos urbano, ordem rica e complexa, foi sufocado pela ordem mecânica, redutiva, frívola. Para Berman, a cidade funcionalista segregou os espaços e "neutralizou as forças anárquicas e explosivas que a modernização havia reunido”. A célebre frase de Le Corbusier, enunciada em 1929 - "Precisamos matar a rua" - (já que de acordo com ele, o novo homem precisaria de um outro tipo de rua), sintetiza com precisão o objeto de tantos ataques ${ }^{8}$. A relação dos críticos ao planejamento urbano[,] e especialmente à técnica do zoneamento, é muito vasta. Lefebvre foi mais longe em sua atraente radicalidade, identificando o planejamento (ou o urbanismo, indiferentemente) como o pior inimigo do urbano ao destruir a vida cotidiana (MARICATO, 2000, p. 7).

No caso específico da configuração urbana do Brasil, a urbanização ocorreu predominantemente no século XX, sob a influência dos dogmas do movimento moderno, na busca por inserção no contexto internacional, em conjunção com a constituição de uma linguagem própria a fim de conformar uma identidade nacional. Essa releitura orientou a prática de uma arquitetura “[...] absolutamente extraordinária que nada tem a ver com o cotidiano (dramático) ou com a gigantesca escala dos problemas das nossas cidades. Especialmente no ensino de arquitetura, o que se persegue é um outro tipo de descolamento em relação à realidade, que não deixa de ser também alienante" (MARICATO, 2000, p. 18).

Se, por um lado, existia um engajamento utópico na leitura modernista nacional, por outro, essa tentativa de "acerto da maioridade precoce" do Brasil com o movimento internacional, sem a revisão de estruturas socioeconômicas, reduziu nossa leitura do modernismo a arquétipos formais esvaziados da utopia social. Como disse Otília Arantes: ficou “sem assunto" (apud MARICATO, 2000, p. 18).

No que concerne ao urbanismo, houve, principalmente ao longo da segunda metade do século XX, um descolamento da "[...] matriz funcionalista modernista em relação à realidade urbana [...]”, chamada por Maricato (2000, p. 11) de matriz

8. Segundo Maricato (2000, p. 7), “as citações foram retiradas de FALCOSKI 1997 [e] se referem a trabalhos bastante conhecidos de Jane Jacobs, Marshall Berman, Le Corbusier e Henri Lefebvre”. 
postiça, responsável pela caracterização do planejamento no capitalismo semiperiférico. Aos planos, cujo desenho do edifício isolado no lote e do programa monofuncional deu ênfase à homogeneidade e à segregação no tecido urbano "formal", somou-se uma política excludente em que a parcela "informal” não foi considerada parte da cidade.

Posto isso, a compreensão da produção do espaço como um processo dialético (material e social) evidencia a possibilidade de caminhos alternativos para se pensar em diferentes formas de apropriação e significação de espaços urbanos comuns.

\section{Estrutura e método da pesquisa}

A pesquisa aqui detalhada foi estruturada em três partes. A primeira parte analisa legislações do município de São Paulo do século XX, sobretudo um conjunto normativo da década de 1970, apresentando seus resultados morfológicos e arquitetônicos como fontes documentais que servem de base para a compreensão da forma urbana atual. Para tanto, os principais objetos de estudos compõem-se de legislações urbanísticas que incidiram diretamente sobre o uso e a ocupação do solo, em especial o Plano Diretor de Desenvolvimento Integrado, $\mathrm{n}^{\circ}$ 7.688, de 1971 (SÃO PAULO (Município), 1971), e sua lei complementar, Lei Geral de Zoneamento, $n^{\circ}$ 7.805, de 1972 (SÃO PAULO (Município), 1972).

As leis mencionadas implementaram no município paulistano parâmetros urbanísticos antagônicos ao tecido urbano até então existente e orientaram uma nova produção espacial, em particular no tocante à forma e à inserção de tipos edilícios isolados no lote, os quais, por sua vez, influenciam diretamente no modelo de produção do espaço urbano e na reprodução das relações sociais, em grande medida vigentes até hoje.

Dado que o objetivo dessa parte é servir de sustentação para a compreensão da produção do espaço urbano, o debate fundamenta-se na análise documental das leis selecionadas e na revisão da literatura sobre o tema. Para tanto, a pesquisa se ampara em estudos de Rolnik, Kowarick e Somekh; Feldman; Nakano e Guatella; Nobre e Noto - que abordam o histórico de legislações urbanísticas do município de São Paulo e suas influências sobre os tipos construídos, preço e segregação socioespacial -; trata-se de uma bibliografia base, à qual se soma a fala de Benjamin Adiron Ribeiro, coordenador incumbido da elaboração das leis em foco, em entrevista a Jorge Pessoa de Carvalho (2008).

A segunda parte apresenta um conjunto normativo a partir de 2002, trinta anos depois da aprovação da Lei Geral de Zoneamento do Município de São Paulo, quando foi promulgado o PDE, Lei $n^{\circ}$ 13.430, com base nos instrumentos urbanís- 
ticos determinados no Estatuto da Cidade em 2001, considerados formatadores de um novo paradigma de produção espacial.

Em 2014 e 2016, foram promulgados, respectivamente, o PDE de 2014, Lei $n^{0} 16.050$, e a LPUOS de 2016, $n^{0} 16.402$, que implementaram estratégias e mecanismos jurídicos e morfológicos de ordenamento territorial que prefiguram transgredir o conceito de "habitat", entendido como uma "função isolada", em busca da inserção na lógica de sociabilização da cidade, o "habitar”, que se refere "às mais diversas manifestações da vida urbana”, nos termos de Henri Lefebvre (2001, p. 134).

Entre as legislações estudadas, e considerando a diversidade de estratégias de uso e ocupação do solo no território da cidade de São Paulo, são circunscritos os parâmetros urbanísticos específicos que orientaram tipos de edifícios com fachada ativa, entendidos como uma inflexão à lógica do edifício isolado no lote. Em virtude da atualidade e da pouquidade de literatura sobre o objeto de pesquisa, as fontes de estudo são teses e artigos recentes; dados de entrevistas com responsáveis pela construção técnica e política e pelo monitoramento das leis urbanísticas estudadas; e, em grande medida, as próprias legislações em análise, com destaque para seus objetivos e normativas mediante citações diretas. Tais dados subsidiam o debate da terceira parte.

Por fim, a terceira parte espacializa e qualifica os artigos referentes à fachada, compreendendo a relação do objeto arquitetônico com o tecido urbano ${ }^{9}$ induzido depois do PDE de São Paulo de 2014, principalmente pela LPUOS, de 2016.

Em 17 de setembro de 2019, a Secretaria Municipal de Desenvolvimento Urbano (SMDU) da Prefeitura de São Paulo disponibilizou no Portal Gestão Urbana o relatório de cinco anos do PDE. Nele constam indicadores da implementação das políticas públicas objetivadas no Plano Diretor de 2014, conforme estipula o artigo 358 da mesma lei. Dentre aqueles, contudo, não havia dados sobre lançamentos imobiliários com fachada ativa, do ponto de vista tanto quantitativo como qualitativo.

Em face da ausência de dados no relatório, foram conduzidas conversas com membros da Prefeitura de São Paulo, atuantes na SMDU, coordenadoria de Planejamento Urbano (SMDU/Planurbe), entre eles André Pina, Daniel Montandon e fundamentalmente Rafael Mielnik (2019), assessor técnico responsável pelo monitoramento e avaliação da implementação do PDE. Foram avaliados dois métodos para a obtenção de dados:

9. Abordagem apresentada por Aragão (2006) como "tipo-morfológica”, isto é, estudo que analisa os tipos edificados em relação ao tecido urbano. ARAGÃO, S. O estudo dos tipos-interfaces entre tipologia e morfologia urbana e contribuições para o entendimento da paisagem. Geosul, Florianópolis, v. 21, n. 42, p 29-43, jul.-dez. 2006. 
1. A análise de processos aprovados, divulgados na página da internet https://www.prefeitura.sp.gov.br/cidade/secretarias/licenciamento/servicos/index.php?p=3334. Dentro de cada planilha mensal há diversas informações sobre cada empreendimento, como o código SQL, a categoria de uso e a zona de uso atual. Com a informação SQL, é possível averiguar detalhes de cada projeto, disponibilizados nos documentos de consultas de obras e edificações, na página https://www.prefeitura.sp.gov.br/deolhonaobra.

2. O estudo das planilhas de cálculo do valor de Outorga Onerosa do Direito de Construir (OODC), arquivadas no Departamento de Uso do Solo da Secretaria Municipal de Urbanismo e Licenciamento (SMUL/DEUSO), com a concessão de incentivos para os empreendimentos que adotam a fachada ativa.

No primeiro método, constatou-se a falta de um padrão que especificasse a utilização de fachada ativa no preenchimento do alvará. Esse resultado não significa, no entanto, que o projeto não a tenha adotado - trata-se apenas da indicação de que essa informação pode não estar presente no documento. A partir de 2019 notou-se, nos alvarás de execução, o uso mais frequente da discriminação de fachada ativa. No segundo método, seria possível averiguar usos não residenciais não computados no térreo, o que indicaria a incidência de fachada ativa. Todavia, a quantificação de empreendimentos por essa análise não seria factível para esta pesquisa, na medida em que esses registros são manuais.

Tais observações revelaram que os procedimentos seriam inviáveis para obter a informação pretendida e demonstraram a carência de sistematização desses dados por parte da Prefeitura de São Paulo, que são extremamente importantes para o planejamento da produção da cidade, ao lado de outras diretrizes do PDE. Mapas, gráficos, modelos tridimensionais e estudos de empreendimentos com fachada ativa foram considerados instrumentos metodológicos substanciais para a análise do tema, em virtude de tais ensaios e exemplares possibilitarem a compreensão das potencialidades e das problemáticas da forma urbana que eles envolvem.

\section{São Paulo, século XX: a configuração do tipo isolado no lote}

\subsection{Contexto antecedente à Lei Geral de Uso e Ocupação do Solo de 1972}

A preocupação com o entendimento espacial e social do uso do solo urbano, como regramento com diretrizes urbanísticas, se esboça na cidade de São Paulo na primeira metade do século XX, quando, em 19 de novembro de 1929, o então prefeito José Pires do Rio anuncia que a Câmara Municipal havia decretado o Código de 
Obras Arthur Saboya, cujas normativas foram consolidadas pelo Ato 663 em 1934 . O Código, relacionado ao surgimento de edifícios verticalizados, disciplinou o uso e a ocupação do solo apenas para alguns perímetros em ruas do município com obrigatoriedade de ocupação sem recuos frontais e laterais (SÃO PAULO (Município), 1934). Segundo Meyer, Cunha Jr. e Fontenele (2018):

Os gabaritos eram calculados em função da largura do viário no qual o novo edifício seria erguido. [...] Apesar de suas inegáveis qualidades, o código Saboya se mostrou, muito rapidamente, aquém das necessidades e, sobretudo, das possibilidades abertas pelo plano de Prestes Maia. As obras do novo sistema criavam e valorizaram novas áreas urbanas ao permitir e estimular a expansão das atividades centrais para fora do Centro Velho.

Já nos anos 1930 e 1940, uma série de dispositivos legais induziu uma conformação morfológica concordante ao Plano de Avenidas em um perímetro de irradiação na área central. A lógica de tais normativas é paradigmática no que tange ao desenho urbano, uma vez que associa a ocupação perimetral de base (com gabaritos contínuos de fachada, galerias comerciais no térreo) com a tecnologia da verticalização, condizente com a conjuntura de uma metrópole emergente, mas cujas torres deveriam atender exigências de recuos mínimos com base em uma altura mínima estabelecida.

A autonomia dos corpos elevados em relação à base permitiu a característica ímpar de diversos exemplares construídos sob essas normativas: a sintaxe da arquitetura moderna em uma composição de desenho urbano da quadra tradicional do século XIX (MEYER; CUNHA JR.; FONTENELE, 2018). São exemplos desse processo os edifícios Cine Ipiranga (1941-1943), de Rino Levi; Arlinda (1959) e Itália (1953-1956), de Franz Heep; Copan (1951-1966) e Eiffel (1952-1955), de Oscar Niemeyer, entre outros ${ }^{10}$. Concomitantemente às leis das décadas de 1930 e 1940, que estipulavam o desenho de quadra (como o Código Arthur Saboya de 1934 e o Decreto-lei $n^{\circ}$ 92, de 2 de maio de 1941), há outras legislações incidentes em áreas conjuntas ao centro com exigências de recuo do edifício em relação ao lote, como a Lei $n^{\circ} 3 \cdot 571$, de 7 de abril de $1937^{11}$.

\footnotetext{
10. Para maior aprofundamento no tema, verificar a tese de doutorado de Felipe Noto, intitulada O quarteirão como suporte da transformação urbana de São Paulo e o texto "Centro Novo de São Paulo. Um projeto de chão” (2018), disponível na revista Vitruvius, de autoria de Regina Meyer, Jaime Cunha Jr. e Sabrina Fontenele.

11. Lei $n^{\circ}$ 3.571, de 7 de abril de 1937: "Art. $1^{\circ}$ As exigências do corpo do artigo 40 do Ato 663 são aplicáveis ás avenidas Paulista, Higienópolis, Angélica, Pedro I, Pompeia e rua Maranhão, mantidos os recuos estatuídos em lei. [...] Art. $3^{\circ}$ Nas vias públicas para as quais vigoram as disposições citadas no artigo $1^{\circ}$,
} 
Em 1957, é promulgada a Lei municipal n 5.261, que será a mais restritiva até a década de 1970, ao instituir pela primeira vez o coeficiente de aproveitamento (CA) igual a 6 para edifícios comerciais e 4 para edifícios residenciais. Entretanto, segundo Rolnik, Kowarick e Somekh (1991, p. 10), “[...] os promotores imobiliários, num primeiro momento, opuseram-se ao projeto [de lei], mas seguiram a recomendação de aprovar imóveis residenciais como comerciais e, desse modo, o coeficiente de aproveitamento máximo real passou a ser 6”. A padronização do CA máximo igual a 6 , independentemente do programa do edifício, será regulamentada pela Lei ${ }^{\circ} 6.877$, de 1966, e a diminuição desse parâmetro terá, em 1972, valor substancial para o debate que acentua o isolamento do edifício no lote.

\subsection{Plano Diretor de Desenvolvimento Integrado de 1971 e Lei Geral de Zoneamento de 1972}

Segundo Feldman (2005, p. 114), o "zoneamento convencional” (zoning norte-americano), cuja característica se pautava em uma preocupação programática e na negligência com a forma urbana, serviu de referência, ao longo do século XX, para debates e proposições de engenheiros e urbanistas radicados em São Paulo. A primazia programática estava evidente em 1971, quando se promulgou o Plano Diretor de Desenvolvimento Integrado (PDDI) e, em 1972, quando se configurou a Lei ${ }^{\circ} 7.805$, ou Lei Geral de Zoneamento do Município de São Paulo.

O zoneamento em questão regulamentou parâmetros voltados à configuração de unidades urbanas, com predominância de uso (FELDMAN, 2005, p. 241), estruturadas por uma rede de vias e com centralidades comerciais e de serviços que irradiariam suas influências nas mais diversas escalas ${ }^{12}$ (RIBEIRO, 2015).

A Lei de Zoneamento definiu para cada zona parâmetros de ocupação e categorias de usos. Adicionalmente, propôs a diminuição do CA máximo 6 - vigente desde a Lei $n^{\circ} 6.877$ de 1966 - para 3,5 apenas na Z5, que corresponde a 1\% da área da cidade (basicamente a área do Centro Histórico e da avenida Paulista); CA 2,5 e 3, respectivamente, na $Z_{3}$ e na $Z 4$, representando 10\% da área urbana; e CA 1 na $\mathrm{Z} 2$, correspondente a quase 70\%, o que causou grande incômodo nos investidores do setor imobiliário (CARVALHO, 2008, p. 48). Essa conjuntura sucedeu a criação do instrumento urbanístico elaborado sob a coordenação de Benjamim Adiron Ribeiro denominado "fórmula de Adiron"13 - já concebida na proposta de 1952, de

só serão permitidas construções coletivas (casas de apartamentos) quando afastadas no mínimo três metros das divisas do lote, devendo as fachadas laterais e posteriores receber tratamento arquitetônico idêntico ao das fachadas principais”. Disponível em: https://bit.ly/3ghtkis. Acesso em: 10 jun. 2019.

12. Desde a escala elementar, que seria a distância de $500 \mathrm{~m}$ de caminhada até a escala de distrito.

13. Lei municipal $n^{\circ}$ 7.805, de 1 novembro de 1972, art. 24. Disponível em: https://bit.ly/3qqZNYd. Acesso em: 10 jun. 2019. 
Henrique Neves Lefevre (FELDMAN, 2005, p. 273) -, o que agravou a produção de edifícios isolados no lote (NAKANO; GUATELLA, 2015, p. 146-147).

Em síntese, a fórmula consolidada em negociação com representantes vinculados à produção imobiliária, em especial o Sindicato das Empresas de Compra e Venda, Locação e Administração de Imóveis do Estado de São Paulo (Secovi) ${ }^{14}$ e 0 Sindicato da Indústria da Construção Civil e Grandes Estruturas do Estado de São Paulo (Sinduscon), permitiu um padrão de verticalização baseado no aumento do coeficiente de aproveitamento até o limite de quatro vezes a área do terreno nas zonas Z3, Z4 e Z5, assim como até o limite de duas vezes na Z2 para a categoria R3 (conjuntos residenciais) com cinquenta habitações ou mais, mediante diminuição da taxa de ocupação (TO) ${ }^{15}$ (FELDMAN, 2005, p. 273-275).

Como decorrência da manutenção dos princípios da fórmula de Adiron por mais de quarenta anos, multiplicou-se o tipo do edifício isolado no lote, visto que o mercado do setor imobiliário, em grande medida, optava pelo acréscimo de área construída em menor área de projeção e, consequentemente, com o aumento da altura dos edifícios ${ }^{16}$.

Em 1992, o Código de Obras do Município, Lei n 11.228 (SÃO PAULO (Município), 1992) ${ }^{17}$, estabeleceu faixas de ventilação e iluminação livres diretamente relacionadas com a altura da edificação. Essas exigências resultavam em recuos muito mais restritivos que os estabelecidos pelo zoneamento de 1972 e acentuaram a implantação do edifício no centro do lote. Com sua desarticulação espacial e formal em relação ao tecido urbano, contrastante com a morfologia urbana de ocupação perimetral de quadra, esse tipo contribuiu para a progressiva inibição da fachada ativa e dos usos mistos nos lotes ${ }^{18}$, em que a aproximação entre o campo privado e o público é essencial (CARVALHO, 2008, p. 58).

\footnotetext{
14. Maricato (1987) relata que o Secovi é a entidade que, após a criação do Banco Nacional de Habitação (BNH), representa os interesses dos grandes empresários da construção civil. MARICATO, E. Política habitacional no regime militar. Rio de Janeiro: Vozes, 1987. p. 83.

15. Segundo Adiron Ribeiro, em entrevista a Jorge Pessoa de Carvalho (2008), as vantagens relativas à obtenção de espaço em torno das edificações consistiam em desenvolver projetos mais limpos do ponto de vista formal e oferecer melhor ventilação e insolação, além de mais áreas de infiltração nas edificações para as águas pluviais (RIBEIRO, 2015).

16. No caso dos lotes contidos na Z2, ao aplicar a fórmula de Adiron, poder-se-ia duplicar o CA, contanto que se diminuísse a TO para $25 \%$. Isso resultaria em um edifício quatro vezes mais alto do que o que não aplica a mesma fórmula.

17. Faixas de ventilação e iluminação já eram exigidas desde o Código de Edificações, Lei nº 8.266, de 1975 (SÃO PAULO (Município, 1975), denominadas faixas livres A1 e A2. Em 1992, essa lei foi revogada pelo Código de Obras do Município, Lei $\mathrm{n}^{\circ}$ 11.228, com o estabelecimento de novas regras para faixas de ventilação “A” e iluminação "I”. SÃO PAULO (Município). Lei nº 8.266 de 20 de junho de 1975: Aprova o código de edificações, e dá outras providências. Diário Oficial da Cidade de São Paulo. São Paulo: Prefeitura do Município de São Paulo.

18. Inibição do uso misto no lote, não na quadra.
} 


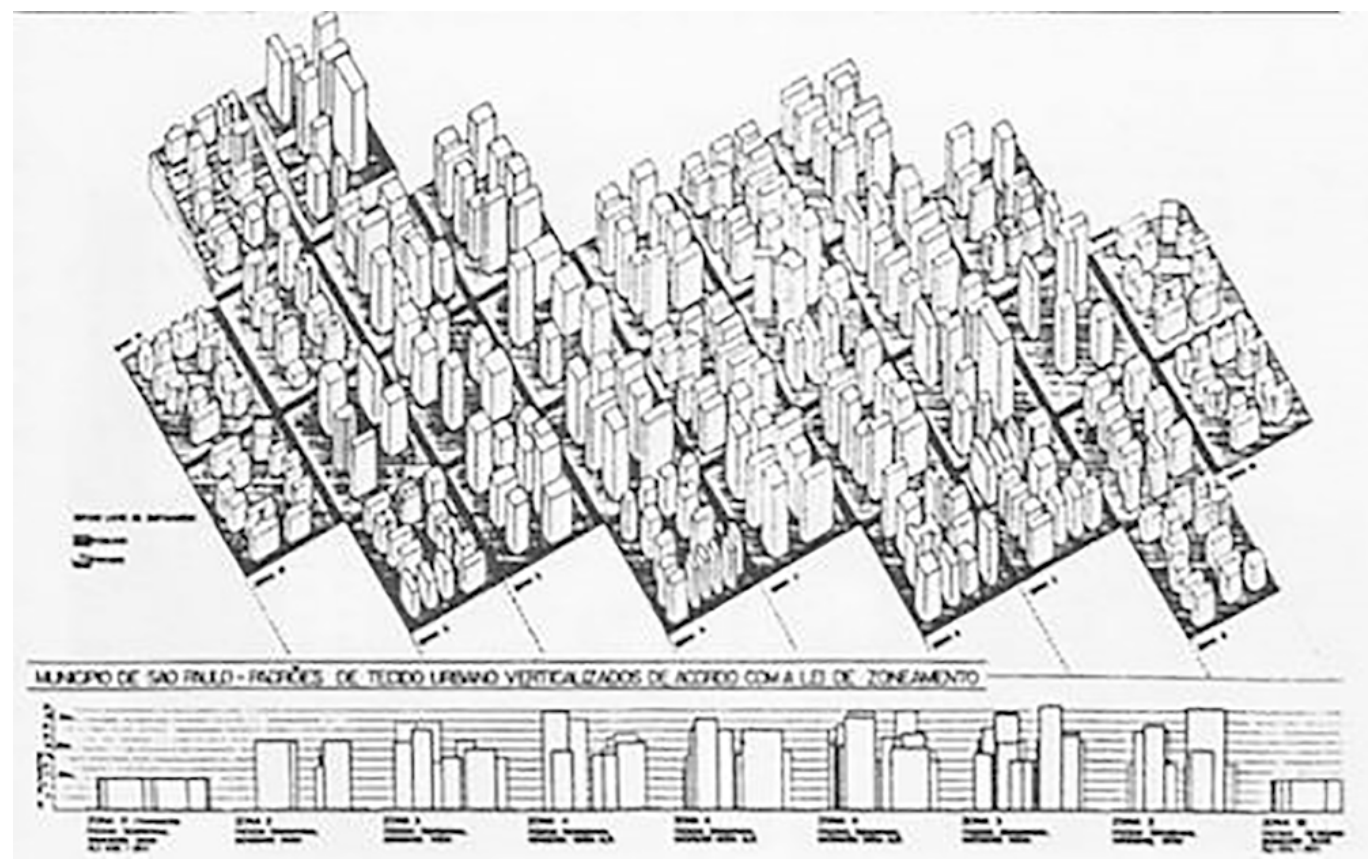

Figura 2. Desenho esquemático da morfologia urbana da quadra após instituição da Lei Geral de Uso e Ocupação do Solo do município de São Paulo (1972)

Fonte: Rolnik (2015).

Em entrevista a Jorge Pessoa de Carvalho, Adiron Ribeiro comenta que houve propostas dos representantes do Secovi como alternativas para a não aplicação da proporção inversa entre CA e TO. Foi sugerida, por exemplo, a contrapartida financeira paga à prefeitura a fim de adquirir potencial construtivo, o que na época não foi aceito por Adiron, por considerar que “[...] esbarraria na ética profissional [...]" (CARVALHO, 2008, p. 56). A Outorga Onerosa foi usada pela primeira vez em São Paulo apenas em 1991, limitada à região da Operação Urbana Anhangabaú, Lei $n^{\circ}$ 11.09o. Tal instrumento foi aprovado pelo Estatuto da Cidade em 2001 e implementado no município paulistano por meio do seu PDE, em 2002 (CARVALHO, 2008, p. 57).

\section{Legislações posteriores ao Estatuto da Cidade: novos paradigmas espaciais?}

4.1 Plano Diretor Estratégico de 2002 e Lei de Parcelamento, Uso e Ocupação do Solo de 2004

Em 2002, após trinta anos da aprovação da Lei Geral de Zoneamento do município de São Paulo, foi promulgado o PDE, pela Lei $n^{0}$ 13.430, e em 2004 sua subsequente LPUOS, Lei n⿳0 ${ }^{13.885}$ (SÃO PAULO (Município), 2004), ambas com base nos instrumentos urbanísticos determinados no Estatuto da Cidade em 2001.

Se, por um lado, o PDE de 2002 e a LPUOS de 2004 representaram um aprimoramento no debate de instrumentos que orientaram o desenvolvimento da 
cidade quanto aos temas jurídico-econômicos e da função social da propriedade ${ }^{19}$ entre eles a Outorga Onerosa ${ }^{20}$; o Parcelamento, Edificação ou Utilização Compulsórios do solo urbano não edificado e não utilizado ${ }^{21}$; o IPTU progressivo no tempo -, mesmo com a ressalva de possuírem "limitações" (BONDUKI, 2011, p. 27), esse aperfeiçoamento, por outro lado, não foi desenvolvido no âmbito de estudos morfológicos capazes de problematizar as estratégias de inserção do edifício no lote e sua relação com a cidade (NAKANO; GUATELLA, 2015, p. 143; MONTANDON, 2016, p. 79).

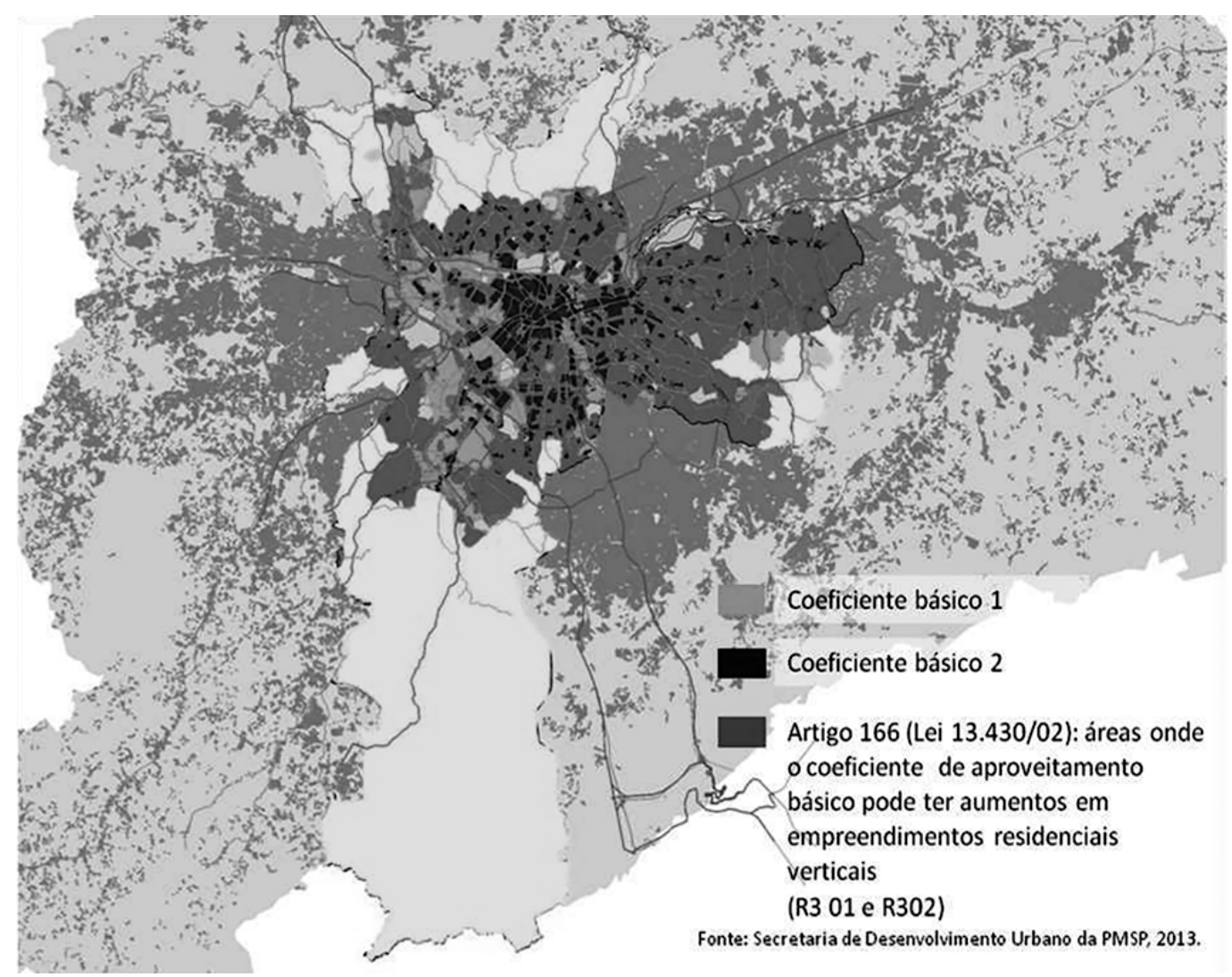

Figura 3. Áreas onde o coeficiente de aproveitamento básico pode majorar mediante diminuição da taxa de ocupação (segundo o PDE de 2002)

Fonte: Nakano; Guatella (2016, p. 148).

19. "A aplicação de instrumentos para fazer valer a função social da propriedade [...] visava conter a especulação com imóveis ociosos bem localizados. Nesse sentido, eles cumprem um papel estrutural de aproveitar os terrenos bem situados na cidade para absorver o crescimento urbano" (BONDUKI; ROSSETTO, 2018, p. 191).

20. Art. 146. XVI - Outorga Onerosa é a concessão, pelo Poder Público, de potencial construtivo adicional acima do resultante da aplicação do Coeficiente de Aproveitamento Básico, até o limite estabelecido pelo Coeficiente de Aproveitamento Máximo, de alteração de uso e parâmetros urbanísticos, mediante pagamento de contrapartida financeira (SÃO PAULO (Município), 2002).

21. Somente após dois encaminhamentos de projetos de lei (PLs), em 2005 e em 2009, o instrumento foi regulamentado em 2010, pela Lei ${ }^{\circ}$ 15.234. Contudo, conforme Bonduki e Rossetto, “[...] as poucas notificações efetuadas entre 2011 e 2013 não tiveram qualquer resultado efetivo, pois não geraram qualquer obrigação legal para o proprietário” (BONDUKI; ROSSETTO, 2018, p. 217-218). 
Como explicado por Daniel Montandon (2016), no PDE de 2002 o coeficiente de aproveitamento básico variava de 1 a 2 com base em duas regras, uma com valores absolutos predeterminados, e a outra com a flexibilidade de majoração de 1 no valor do coeficiente básico, atingindo 2 , sob a condição de diminuir a taxa de ocupação. Tal permissão, além de reiterar formas urbanas da legislação de 1972, contradizia a lógica de aplicação da Outorga Onerosa, uma vez que "[...] incidiu em apenas $12,5 \%$ do total dos empreendimentos imobiliários no período de vigência do PDE” (MONTANDON, 2016, p. 79); portanto, diminuiu o arrecadamento com a valorização imobiliária gerada, que deveria ser destinada ao Fundo de Desenvolvimento Urbano (Fundurb) ${ }^{22}$ e revertida em melhorias para a coletividade.

Art. 166 - Nas atuais zonas Z2, Z11, Z13, Z17 e Z18 [zonas de uso predominantemente residencial, em que são permitidos comércio e serviços de âmbito local e diversificado] e nos corredores de uso especial a elas lindeiras, até a revisão da legislação de parcelamento, uso e ocupação do solo, para categoria de uso R3 01 e R3 02 [empreendimentos imobiliários residenciais verticais], o coeficiente de aproveitamento básico poderá ser beneficiado de acréscimo, limitado a 1,0 (um), sem o pagamento de contrapartida, mediante a redução da taxa de ocupação permitida, segundo a seguinte equação: $\mathrm{CAu}=\mathrm{TO} /$ TOu x CAb ${ }^{23}$ (SÃO PAULO (Município), 2002).

Art. 297 - Nas zonas Z3, Z4, Z5, Z10 e Z12 [zonas de uso predominantemente residencial e zonas de uso misto] da legislação de Parcelamento, Uso e Ocupação do Solo em vigor, o coeficiente de aproveitamento básico poderá, mediante a redução de taxa de ocupação permitida, segundo a equação expressa no artigo 166 desta lei e a manutenção de área permeável equivalente a no mínimo 15\% (quinze por centro) da área do lote e a reserva de no mínimo 50\% (cinquenta por cento) da área não ocupada para jardim, ser beneficiado de acréscimo, podendo chegar a: 4,0 (quatro), no exercício de 2002; b) 3,0 (três), no exercício de 2003 (SÃO PAULO (Município), 2002).

Em 2004, a LPUOS reafirmou incentivos aos tipos de empreendimentos imobiliários residenciais verticais isolados no lote (Art. 240), como se vê a seguir:

Art. 240. Até a revisão do PDE e PREs, independentemente do coeficiente de aproveitamento máximo estabelecido nos planos estratégicos regionais, fica mantido o incentivo à produção habitacional

22. "O Fundurb foi concebido como um instrumento de caráter redistributivo [...]. No entanto, como a lei de 2002 não estabeleceu prioridades, o fundo se tornou entre 2003 e 2014 uma espécie de caixa suplementar para a prefeitura viabilizar obras que em situações normais seriam realizadas com recursos do orçamento" (BONDUKI; ROSSETO, 2018, p. 234-235).

23. $\mathrm{CAu}=$ Coeficiente de Aproveitamento a ser utilizado. $\mathrm{TOu}=$ Taxa de Ocupação a ser utilizada. $\mathrm{TO}=$ Taxa de Ocupação Máxima admitida. CAb = Coeficiente de Aproveitamento Básico. 
expresso nas disposições do artigo 166 do PDE para a categoria de uso R2v²4, nos lotes contidos nas zonas Z2, Z11, Z13, Z17, Z18 e os corredores de usos especiais a elas lindeiros da legislação anterior ao PDE [...]. (SÃO PAULO (Município), 2004, grifo nosso).

No período entre o PDE de 2002 e o PDE de 2014, a conjuntura foi de crescente politização sobre a questão urbana, possibilitando a inserção de novas diretrizes no PDE de 2014, como foi o caso de propostas relativas à qualificação da interface do espaço privado com o espaço público.

\subsection{Concurso Nacional Ensaios Urbanos: Desenhos para o Zoneamento de São Paulo}

Em consequência do reconhecimento de que a legislação de Uso e Ocupação do Solo vigente até 2013 apresentava "[...] mecanismos limitadores ou pouco indutores de tipologias ${ }^{25}$ edificadas [...] integradas ao espaço público [...]” (SÃO PAULO (Município); IAB-SP, 2013, p. 5), a Prefeitura de São Paulo e o Instituto de Arquitetos do Brasil (IAB-SP) - Departamento São Paulo promoveram, no final daquele mesmo ano, o "Concurso Nacional Ensaios Urbanos: Desenhos para o Zoneamento de São Paulo", com o intuito de explorar morfologias baseadas nas diretrizes propostas pelo Projeto de Lei do Plano Diretor (PL 688/13) que pudessem qualificar o desenho urbano e servissem de subsídio para a revisão da Lei nº 13.885, de 2004 (SÃO PAULO (Município); IAB-SP, 2013).

\subsection{Plano Diretor Estratégico de 2014}

No ano de 2013, o PDE de 2002 já havia completado dez anos de vigência; era o momento de revisá-lo, segundo o ciclo decenal estabelecido pelo Estatuto da Cidade. O PDE de 2014, Lei $n^{0} 16.050$, e posteriormente a LPUOS de 2016, Lei $n^{0} 16.402$, implementaram estratégias e mecanismos jurídicos e morfológicos de ordenamento territorial que prefiguram contestações ao tipo do edifício isolado no lote - fomentadas pela "fórmula de Adiron". Essas leis utilizam instrumentos de flexibilização da definição de áreas computáveis de CA, e consequentemente de outorga onerosa, para inibir ou induzir determinadas formas urbanas, como diminuição de áreas destinadas a vagas de garagem, calçadas mais largas, assim como fruição pública no pavimento térreo e estímulo à fachada ativa e edifícios de uso misto.

\footnotetext{
24. Art. 151, inciso III. R2v: conjunto com mais de duas unidades habitacionais agrupadas verticalmente - edifícios de apartamentos ou conjuntos residenciais verticais em condomínio.

25. Conforme Carvalho (2008, p. 40): “Os estudos de tipologias arquitetônicas, assim como a análise urbana pelo método tipológico, nunca foram muito difundidos no Brasil”. Para aprofundamento no tema, cf. ANTONUCCI, D. Morfologia urbana e legislação urbanística: estudos de setores de bairros na cidade de São Paulo no período de 1972-2002. 2005. Tese (Doutorado) - Faculdade de Arquitetura e Urbanismo, Universidade de São Paulo, São Paulo, 2005.
} 
Dos artigos que constam na Lei $\mathrm{n}^{0} 16.050$ referentes à fachada ativa, destacam-se:

[...] Art. 23. Os objetivos urbanísticos estratégicos a serem cumpridos pelos eixos de estruturação da transformação urbana são os seguintes:

[...] VIII - orientar a produção imobiliária da iniciativa privada de modo a gerar:

[...] c) fachadas ativas ${ }^{26}$ no térreo dos edifícios; (SÃO PAULO (Município), 2014, p. 53, grifo nosso).

Art. 27. De acordo com os objetivos e diretrizes expressos neste PDE para macrozonas, macroáreas e rede de estruturação da transformação urbana, a legislação de Parcelamento, Uso e Ocupação do solo - LPUOS deve ser revista, simplificada e consolidada segundo as seguintes diretrizes:

[...] IX - proporcionar a composição de conjuntos urbanos que superem exclusivamente o lote como unidade de referência da configuração urbana, sendo também adotada a quadra como referência de composição do sistema edificado.

[...] XII - estimular o comércio e os serviços locais, especificamente os instalados em fachadas ativas, com acesso direto e abertura para o logradouro; (SÃO PAULO (Município), 2014, p. 54).

Art. 80. Nas áreas de influência dos eixos, serão consideradas não computáveis:

[...] IV - as áreas construídas no nível da rua com acesso direto ao logradouro, em lotes com testada superior a $20 \mathrm{~m}$ (vinte metros), até o limite de 50\% (cinquenta por cento) da área do lote, destinadas a usos classificados nas subcategorias de usos nR1 ou nR2 ${ }^{27}$; (SÃO PAULO (Município), 2014, p. 70).

Art. 176. São objetivos específicos da Política de Desenvolvimento Econômico Sustentável:

[...] IV - incentivar o comércio e os serviços locais, especialmente os instalados em fachadas ativas, junto às ruas; (SÃO PAULO (Município), 2014, p. 100).

Tais parâmetros prefiguram maior apropriação coletiva por meio de um território que diminui a importância do automóvel, que considera o con-

26. 0 termo "fachada ativa” refere-se à “[...] exigência de ocupação da extensão horizontal da fachada por uso não residencial com acesso direto e abertura para o logradouro, a fim de evitar a formação de planos fechados na interface entre as construções e os logradouros, promovendo a dinamização dos passeios públicos (SÃO PAULO (Município), 2014, p. 183; SÃO PAULO (Município), 2016, p. 62).

27. nR1: uso não residencial compatível com a vizinhança residencial; nR2: uso não residencial tolerável à vizinhança residencial. 
junto edificado no lote e sua interface com o logradouro e que proporciona maior heterogeneidade de usos, entre outras medidas de regulação do solo que pressupõem uma antítese ao modelo morfológico segregador induzido pela legislação vigente desde a década de 1970 até a época de sua revisão (SÃO PAULO (Município), 2016, p. 15).

\subsection{Lei de Parcelamento Uso e Ocupação do Solo de 2016}

Seguindo as diretrizes do PDE de 2014, a LPUOS de 2016 especificou parâmetros e mecanismos jurídicos e morfológicos de ordenamento territorial. No que se refere à diretriz de "Qualificar a vida urbana dos bairros", a LPUOS de 2016 reitera:

[...] O novo zoneamento busca garantir o direito das pessoas à cidade, proporcionando diversidade de usos, disponibilidade de espaços verdes e qualidade na relação entre os espaços públicos e privados. Para isso, a nova lei orienta como cada lote deve contribuir para uma melhor convivência nos bairros e na cidade. $O$ atual modelo de produção imobiliária em São Paulo pouco dialoga com o pedestre. Edifícios com calçadas estreitas, muros altos em quadras extensas e empenas cegas são exemplos de como a circulação de pedestre é prejudicada, além de gerar desconforto e insegurança. [...] (SÃO PAULO (Município), 2016, p. 23).

Dos artigos na Lei $\mathrm{n}^{\mathbf{0}} 16.402$ referentes à fachada ativa, tem-se:

[...] Art. 57. São parâmetros qualificadores da ocupação, de modo a promover melhor relação e proporção entre espaços públicos e privados: I - fruição pública; II - fachada ativa; III - limite de vedação do lote; IV - destinação de área para alargamento do passeio público. (SÃO PAULO (Município), 2016, p. 62, grifo nosso)

Art. 62. São consideradas áreas não computáveis ${ }^{28}$ :

VII - as áreas construídas no nível da rua com fachada ativa mínima de $25 \%$ (vinte e cinco por cento) em cada uma das testadas e de no mínimo 3m (três metros) de extensão, destinadas a usos classificados na categoria não residencial que sejam permitidos nas respectivas zonas, até o limite de:

a) 50\% (cinquenta por cento) da área do lote nas ZEU, ZEUa, ZEUP, ZEUPa, ZEM, ZEMP, ZC e ZCa;

b) $20 \%$ (vinte por cento) da área do lote nas demais zonas; (SÃO PAULO (Município), 2016, p. 64)

28. “Art. 62, § $2^{\circ}$ A somatória das áreas construídas não computáveis referidas nos incisos I a VI do 'caput' deste artigo fica limitada a 59\% (cinquenta e nove por cento) do valor correspondente à área construída total da edificação, excluídas as áreas não computáveis previstas nos incisos VII a XVI.” (SÃO PAULO (Município), 2016, p. 64). 
Art. 71. A fachada ativa, ocupada por uso não residencial (nR) localizada no nível do logradouro, deverá:

I - estar contida na faixa de $5 \mathrm{~m}$ (cinco metros) a partir do alinhamento do lote, medida em projeção ortogonal da extensão horizontal;

II - ter aberturas para o logradouro público, tais como portas, janelas e vitrines, com permeabilidade visual, com no mínimo 1 (um) acesso direto ao logradouro a cada $20 \mathrm{~m}$ (vinte metros) de testada, a fim de evitar a formação de planos fechados sem permeabilidade visual na interface entre as construções e o logradouro, de modo a dinamizar o passeio público.

$\S 1^{\circ} \mathrm{O}$ recuo entre a fachada ativa e o logradouro público deve estar fisicamente integrado ao passeio público, com acesso irrestrito, não podendo ser vedado com muros ou grades ao longo de toda a sua extensão, nem ser ocupado por vagas de garagem ou usado para manobra de veículos, carga e descarga e embarque e desembarque de passageiros. (SÃO PAULO (Município), 2016, p. 66-68)

Art. 87. Nas ZEU, ZEUa, ZEUP, ZEUPa, ZEM, ZEMP, ZC e ZCa, quando a área do lote for superior a $10.000 \mathrm{~m}^{2}$ (dez mil metros quadrados) e menor ou igual a $20.000 \mathrm{~m}^{2}$ (vinte mil metros quadrados), será obrigatória a adoção dos seguintes parâmetros qualificadores da ocupação: [...] III - fachada ativa em no mínimo $25 \%$ (vinte e cinco por cento) da testada do lote em empreendimentos residenciais ou não residenciais. (SÃO PAULO (Município), 2016, p. 74)

Art. 126. Nos edifícios-garagem ${ }^{29}$ não incidirá contrapartida financeira da outorga onerosa de potencial construtivo adicional desde que as áreas edificadas nos pavimentos de acesso sejam destinadas a outros usos não residenciais, que possuam a fachada ativa e que seja aplicada no mínimo 50\% (cinquenta por cento) de cobertura verde na edificação. [...] (SÃO PAULO (Município), 2016, p. 92)

Outra diretriz que pode contribuir qualitativamente para o desenho urbano é apresentada no Art. 66 da LPUOS. Nele, os recuos laterais e de fundo são dispensados para quase todas as zonas ${ }^{30}$ cuja edificação tenha até $10 \mathrm{~m}$ de altura, ou quando o vizinho já possua edificação encostada no lote, ou em terrenos com até $250 \mathrm{~m}^{2}$ com declividade ou frente com até $10 \mathrm{~m}$ lineares (SÃO PAULO (Município), 2016, p. 66). Esses parâmetros possibilitam o tipo “edifício base-torre”, na qual se admitem tanto a necessidade de isolamento do edifício para aeração e insolação como o reconhecimento da base, interface entre o espaço do lote e seu entorno público.

29. Conforme a LPUOS de 2016, edifícios-garagem são “[...] edificações em que pelo menos 75\% (setenta e cinco por cento) da área construída total é destinada à circulação, manobra e estacionamento de veículos” (SÃO PAULO (Município), 2016, p. 92).

30. Exceto para ZPI-1, ZPI-2 e ZDE-2. 
É fundamental perceber que, apesar de esse tipo "base-torre" ter sido permitido na LPUOS de 2004 para edificações com até $6 \mathrm{~m}$ de altura (Art. 186), torna-se uma morfologia com potencialidade reduzida em face da presença, na mesma lei, de incentivos financeiramente mais rentáveis para a torre isolada no lote. Dessa forma, compreende-se que o grande progresso da LPUOS de 2016 não foi a possibilidade do tipo base-torre, e sim a não proposição de medidas profusamente contraditórias à própria estratégia.

Por fim, sobre larguras mínimas dos passeios públicos, normatizou-se no Art. $67^{31}$ que, "Em ZEU, ZEUa, ZEUP, ZEUPa, ZEM, ZEMP, ZC, ZCa, ZM e ZEIS, os passeios públicos deverão ter a largura mínima de 5m”, observando os incisos I e II. Nas demais zonas, não há dimensão mínima para a largura do passeio público, exceto nos casos de projeto de parcelamento do solo, em que devem ser observadas as medidas do Quadro 2B da LPUOS de 2016.

\section{Análise dos parâmetros de incentivo à fachada ativa \\ 5.1 Tipos reconhecíveis com fachada ativa}

A análise da morfologia regulamentada pela legislação deriva da compreensão de que, a despeito de boa parte da cidade ser construída pela iniciativa privada, o Estado deve assumir o papel de preceptor do desenho do espaço urbano. Assim, foram modelados neste estudo os parâmetros da legislação urbanística, com a identificação dos tipos de fachada ativa reconhecíveis e sua aplicação em diferentes tecidos do município de São Paulo, a fim de analisar suas potencialidades e limitações em meio à diversidade morfológica existente. $\mathrm{O}$ estudo por meio de tipos resulta do entendimento de que não se deve "[...] tratar de reduzir o desenvolvimento da cidade a um processo tipológico, embora essa evolução dos tipos contribua decisivamente à compreensão do fato social-histórico” (KRAFTA, 1986, p. 19). Ainda: “[...] o tipo ${ }^{32}$ é a chave para compreender a conexão entre os elementos individuais e as formas urbanas, [...] considerados elementos vinculados uns aos outros, que perdem o sentido se não são reconhecidos a partir da

\footnotetext{
31. Somam-se ao Art. 67 complementações sobre a largura de passeios públicos dispostos no Art. $9^{\circ}$ do Decreto Municipal de São Paulo, n 57.521, de 2016.

32. Para Quatremère de Quincy (1825, p. 543, tradução nossa): “A palavra tipo representa não tanto a imagem de uma coisa a ser copiada ou imitada perfeitamente quanto a ideia de um elemento que deve ele mesmo servir de regra ao modelo. [...] O modelo, entendido segundo a execução prática da arte, é um objeto que se deve repetir tal como é; o tipo, pelo contrário, é um objeto de acordo com o qual qualquer pessoa pode conceber obras que em nada se assemelharão. Tudo é preciso e dado no modelo; tudo é mais ou menos vago no tipo. Vemos assim que a imitação dos tipos não tem nada que o sentimento e o espírito não possam reconhecer”. QUINCY, A. C. Q. de. Type. In: Encyclopédie Methodique - Architecture. Liège: chez Panckoucke, 1825. t. III.
} 
interdependência constatada. Esta atitude, ao destacar a relação dos elementos entre si e com o todo, propõe um método de análise que pode ser chamado de morfológico" (PEREIRA, 2012).

Nesse sentido, o estudo averigua os tipos e suas inter-relações com o propósito de entender se a quadra é configurada como unidade de referência do tecido urbano, com o reconhecimento do quarteirão como elemento de suporte para o desenho e a unidade de qualificação da interface entre o lote e o passeio público. Como defende Felipe Noto (2017, p. 78-79) em sua tese de doutorado, o quarteirão é a unidade primeira em que se verifica a possibilidade de subversão dos limites do lote: “[...] cabe argumentar que o quarteirão é o primeiro elemento coletivo da morfologia urbana, a primeira associação entre particulares que se pode ler como um conjunto reconhecível. E além disso, é desdobramento natural e - praticamente obrigatório - do parcelamento do solo: a criação de um sistema viário necessário para a existência de lotes pressupõe a formação de quarteirões”.

Noto (2017, p. 79) também advoga que, além de ser o primeiro elemento coletivo de associação de particulares, o quarteirão - e as normativas que sobre ele incidem - poderia “[...] funcionar como suporte estável para a forma da cidade, resistindo às alterações de suas peças individuais e às eventuais transformações de uso ao longo do tempo". Com base na leitura da modelagem, busca-se investigar se a forma urbana induzida pela legislação urbanística - resultante especificamente da aplicação dos incentivos à fachada ativa estabelecidos no PDE de 2014 e na LPUOS de 2016 - de fato contesta o tipo do edifício isolado no lote e se contribui para a construção qualitativa da interface do lote com o passeio público.

A modelagem dos parâmetros, realizada nesta pesquisa, é resultado da correlação das normativas contidas nos artigos do PDE de 2014 e da LPUOS de 2016, apresentados nos itens 4.3 e 4.4 deste texto. Para além das normativas destacadas, aplicam-se os parâmetros da LPUOS de 2016 contidos nos Quadros 02A, intitulados "Parâmetros de parcelamento do solo (dimensões do lote) por zona", em que constam dimensões de frente e áreas mínimas e máximas de lotes, e no Quadro 03, "Parâmetros de ocupação, exceto de Quota Ambiental", composto de coeficiente de aproveitamento, taxa de ocupação máxima, gabarito de altura máxima, recuos mínimos de frente, fundo e laterais de acordo com a altura da edificação, além de cota parte máxima de terreno por unidade.

Após os estudos dos parâmetros de ocupação nas diversas zonas do município de São Paulo, foram reconhecidos dois tipos (tipo "torre" e tipo "base-torre") cujas inserções no lote podem ser diversas. 


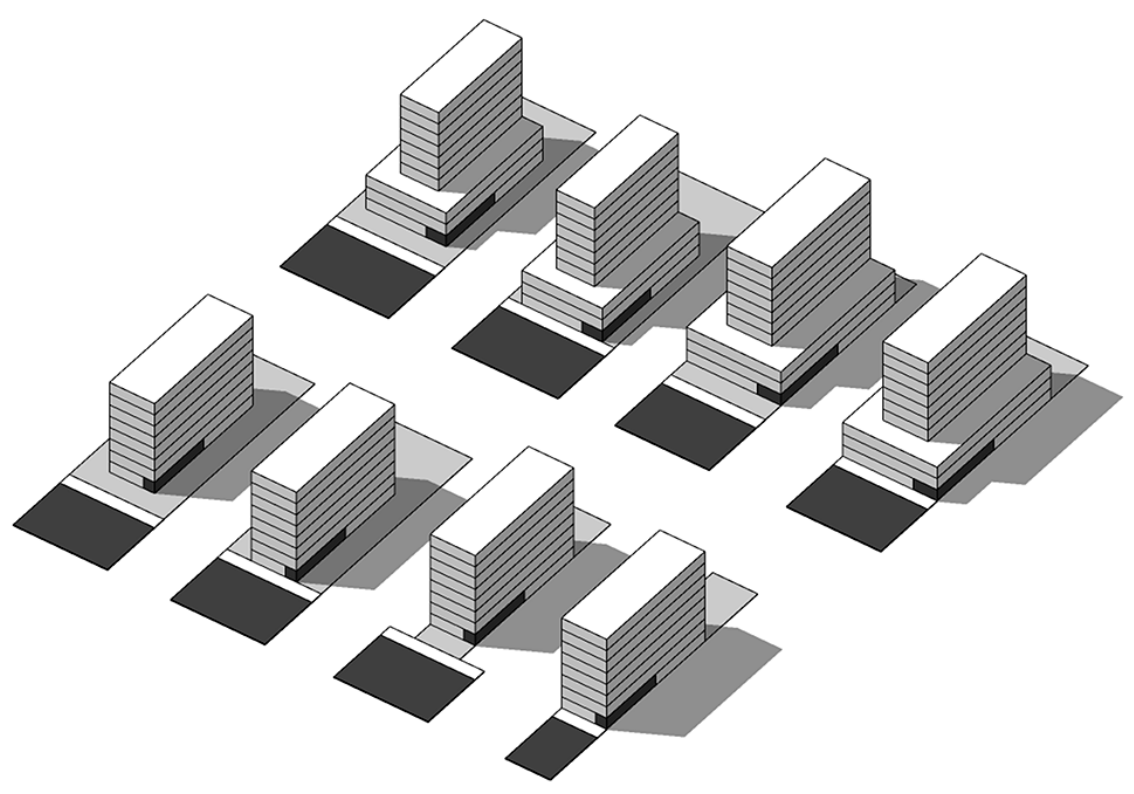

Figura 4. Inserções diversas dos tipos reconhecíveis com fachada ativa Fonte: Elaboração da autora.

Dado o reconhecimento de tais tipos, percebe-se que a qualificação do espaço urbano resulta de uma conjunção de variáveis morfológicas, dentre as quais algumas são objeto de estudo tipológico e outras o extrapolam. São os casos da diversidade de usos e funções dos empreendimentos, das transparências dos planos e da posição dos acessos às edificações, cuja frequência e disposição determinam as trocas entre o espaço do lote e o passeio público.

No que tange somente aos tipos, nota-se que tanto a "torre" como a "base-torre” apresentam possibilidades de qualificação da interface do espaço público com o privado, dependendo da configuração do nível térreo. Edificações distantes do limite frontal do lote ou com grandes dimensões de recuos laterais têm maior propensão a não qualificar positivamente o passeio público. Por sua vez, o contrário não é verdade, pois mesmo edificações cujas bases são limítrofes ao lote podem conter dispositivos que reiterem o ensimesmamento de enclaves.

Deste modo, tanto o tipo torre como o base-torre podem compor ou não a unidade da quadra, desde que seus recuos laterais e frontais não tenham dimensões que provoquem aeração no uso do passeio público. Para empreendimentos com gabaritos de altura maior que $10 \mathrm{~m}$, o tipo base-torre de ocupação perimetral - associada a outras edificações - tem a potencialidade de configurar o quarteirão como referência morfológica sem se opor aos recuos para ventilação e iluminação dos volumes verticalizados. 

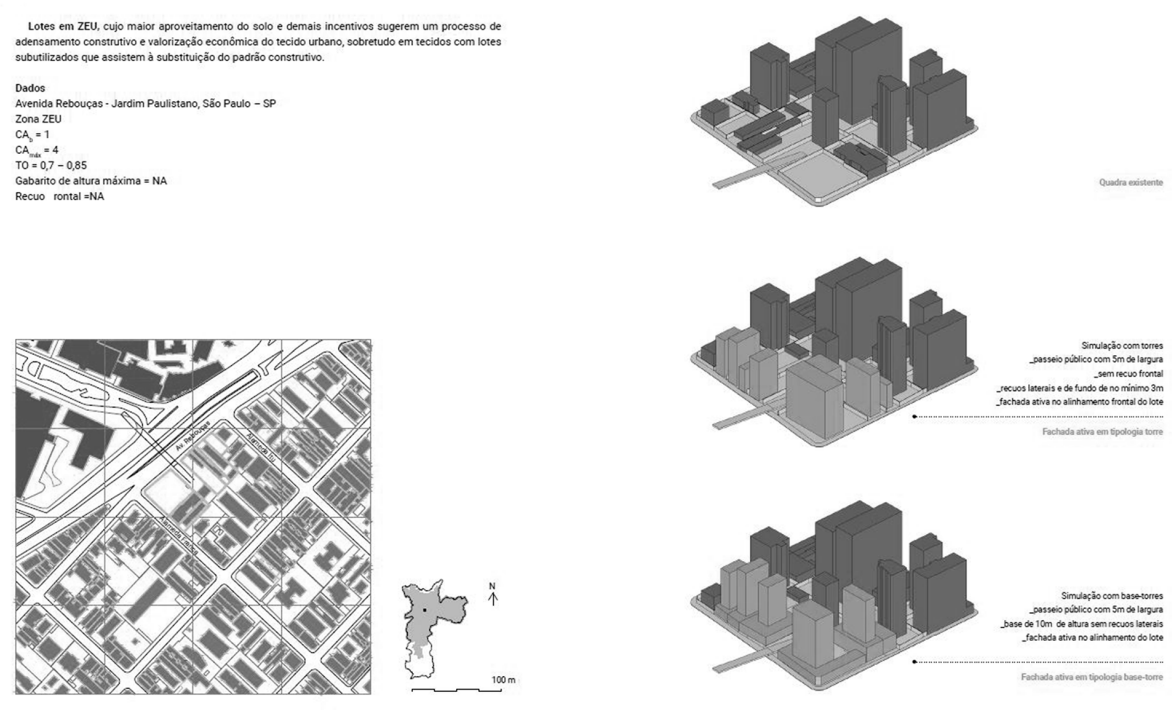

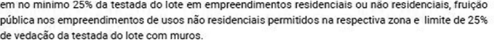
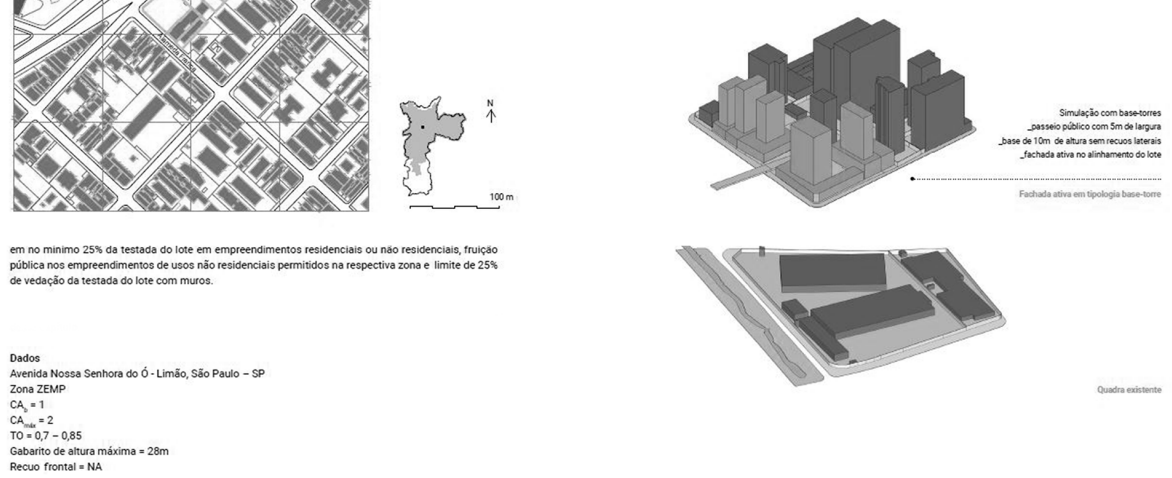

Gabaritio de olturar mixima $=28 m$
Recuo frontal $=\mathrm{NA}$
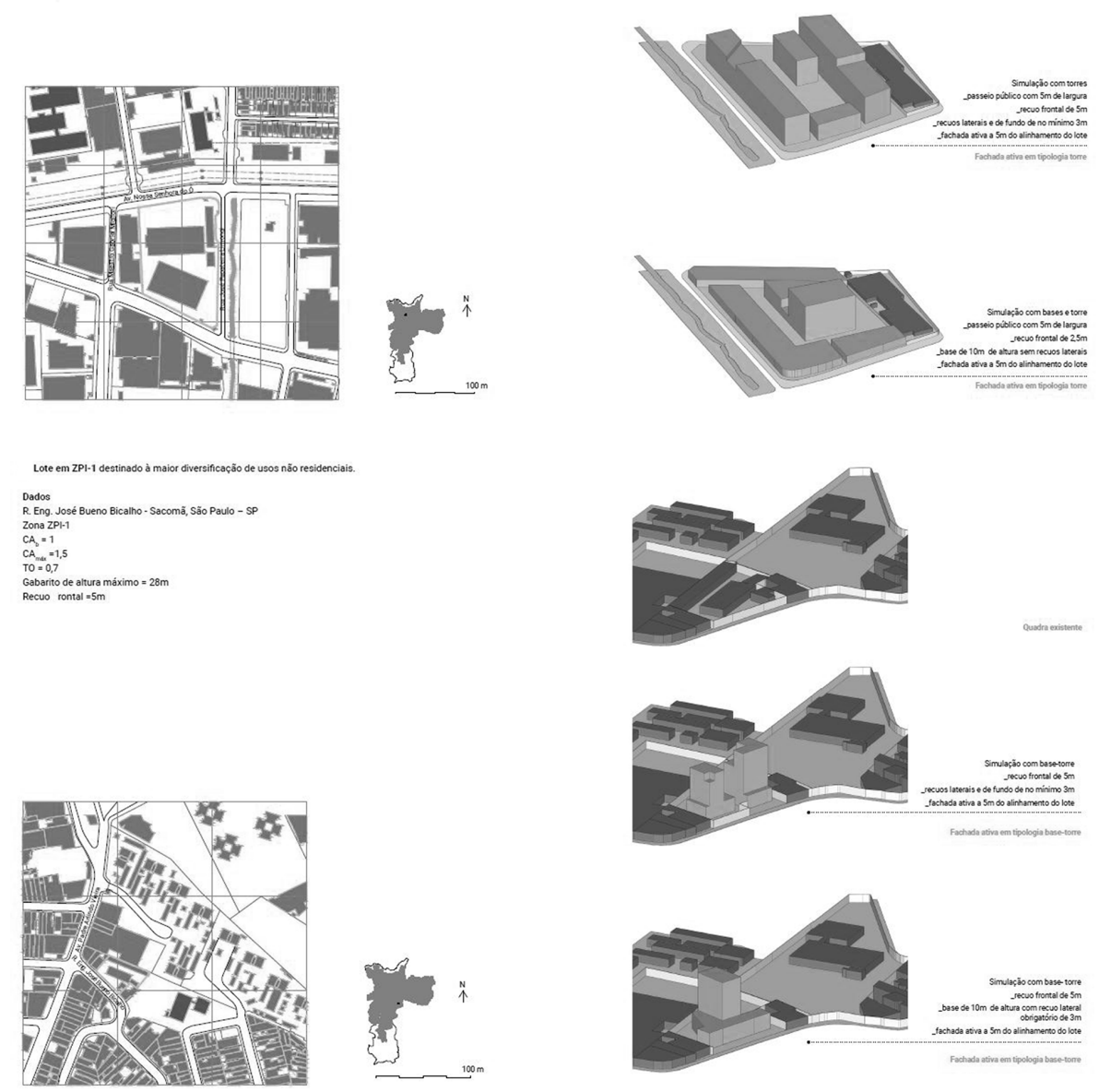

Figura 5. Estudo dos tipos em quadras reais em ZEU, ZC e ZEMP, com incentivos diversos à fachada ativa

Fonte: Elaboração da autora. 
Dessa forma, em ZEU, ZEUa, ZEUP, ZEUPa, ZEM e ZEMP33, como consequência dos $5 \mathrm{~m}$ de largura exigidos para o passeio público e do limite de até $5 \mathrm{~m}$ de recuo frontal opcional, podem-se totalizar $10 \mathrm{~m}$ de largura entre um dos limites da calçada e o início do empreendimento, além dos recuos laterais sem dimensão máxima definida. Se, por um lado, identifica-se que o maior incentivo à estratégia de fachada ativa (até $50 \%$ da área do lote) em ZEU, ZEUa, ZEUP, ZEUPa, ZEM, ZEMP, ZC, ZCa é coerente com o maior adensamento populacional que se deseja nessas zonas, atrelado a requisitos de larguras mínimas de calçada, por outro, permanece a dúvida sobre a facultatividade de recuos frontais no lote e sua obrigatoriedade para as demais zonas.

Extrapolando os estudos tipológicos de inserção do edifício no lote, o Art. 71 da LPUOS de 2016 objetiva qualificar a fachada ativa. Para além da restrição de até $5 \mathrm{~m}$ de recuo frontal desde o alinhamento do lote (medida em projeção ortogonal da extensão horizontal), o artigo normatiza a existência de aberturas para o logradouro, que podem ser portas, janelas ou vitrines, e de um acesso, no mínimo, a cada $20 \mathrm{~m}$ de testada. Tem-se, então, em conjunção com tais determinações:

$\S 1^{\circ}$ O recuo entre a fachada ativa e o logradouro público deve estar
fisicamente integrado ao passeio público, com acesso irrestrito, não
podendo ser vedado com muros ou grades ao longo de toda a sua
extensão, nem ser ocupado por vagas de garagem ou usado para ma-
nobra de veículos, carga e descarga e embarque e desembarque de
passageiros (SÃO PAULO (Município), 2016, p. 68).

Entretanto, ao analisar lançamentos imobiliários publicados como bons exemplares de fachada ativa, apresentados no jornal Estadão e nos meios eletrônicos de grandes construtoras e incorporadoras, como a Helbor e a Magik, percebe-se que eles se apropriam dos incentivos destinados a atender essa diretriz, em conformidade com as normativas da LPUOS de 2016, sem, contudo, estimular a apropriação das calçadas (trocas e encontros). Nesses empreendimentos, o projeto vale-se de recuos frontais de grandes dimensões, de paisagismos, de vidros espessos ou de outras soluções projetuais que sugerem mais fechamento e isolamento do que uma fachada que, por essência, deveria ser ativa, distanciando assim a parcela do público considerada indesejada para aquele espaço. Um exemplo dessa apropriação é dado nos anúncios reproduzidos a seguir (Figura 6).

33. Em ZC e ZCa, o alargamento do passeio público é obrigatório somente para lotes com área superior a $2.500 \mathrm{~m}^{2}$, conforme inciso II do Art. 67 da LPUOS de 2016. 


\section{Uso misto e fachada ativa marcam lançamentos em São Paulo}

Novos projetos adotam diretrizes do novo Plano Diretor, 4 anos após sua aprovação

O empreendimento terá três lojas no andar térreo, cada uma com 500 metros quadrados, dois andares de salas comerciais e 17 pavimentos de residencial, sendo que um deles será inteiramente para a área de lazer.

"O plano permite construir mais, podemos fazer projetos robustos nos mesmos terrenos de antigamente", diz o sócio-diretor da Mar Incorporações, Alexandre Suarez. Na sua opinião, o Luminus vai "servir bem ao paulistano", uma vez que reúne casa, comércio e trabalho.

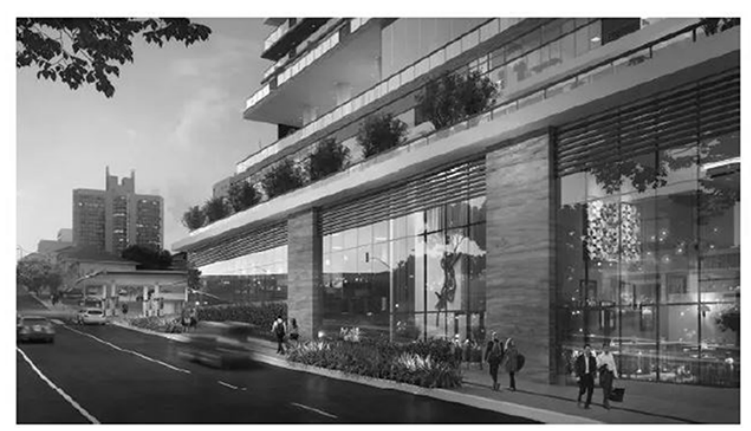

Figura 6. Matéria do Estadão sobre lançamentos imobiliários com fachada ativa. Fachada ativa do Edifício Luminus Jardins. Edifício Luminus Jardins. Rua José Maria Lisboa, 757 Jardim Paulista - São Paulo - SP.

Fonte: Estadão (edição online de 5 ago. 2018).

A constatação dessa potencialidade mitigada aponta três caminhos que deveriam ser considerados. O primeiro trata de uma avaliação e de um monitoramento quantitativos desses exemplares, o que torna possível compreender se os incentivos fiscais têm gerado efeito sobre a produção imobiliária com empreendimentos de fachada ativa. O segundo é a averiguação qualitativa desses empreendimentos, que, embora sigam a lei, não qualificam a produção da cidade como almejado. E o terceiro, com base nos dois primeiros pontos, trata-se do entendimento das potencialidades e das deficiências dos objetivos.

Esse constante questionamento pela prefeitura, parcialmente realizado e de forma ainda limitada ${ }^{34}$, após cinco anos e meio do PDE de 2014 e quase quatro anos da LPUOS de 2016, deve ser progressivamente aperfeiçoado para que seja possível obter uma avaliação precisa do cenário existente e então configurar proposições conscientes sobre a produção da cidade.

34. Informação fornecida por Rafael Mielnik (2019), membro da Prefeitura Municipal de São Paulo (SMDU/Planurbe) e assessor técnico responsável pelo monitoramento e avaliação da implementação do Plano Diretor 

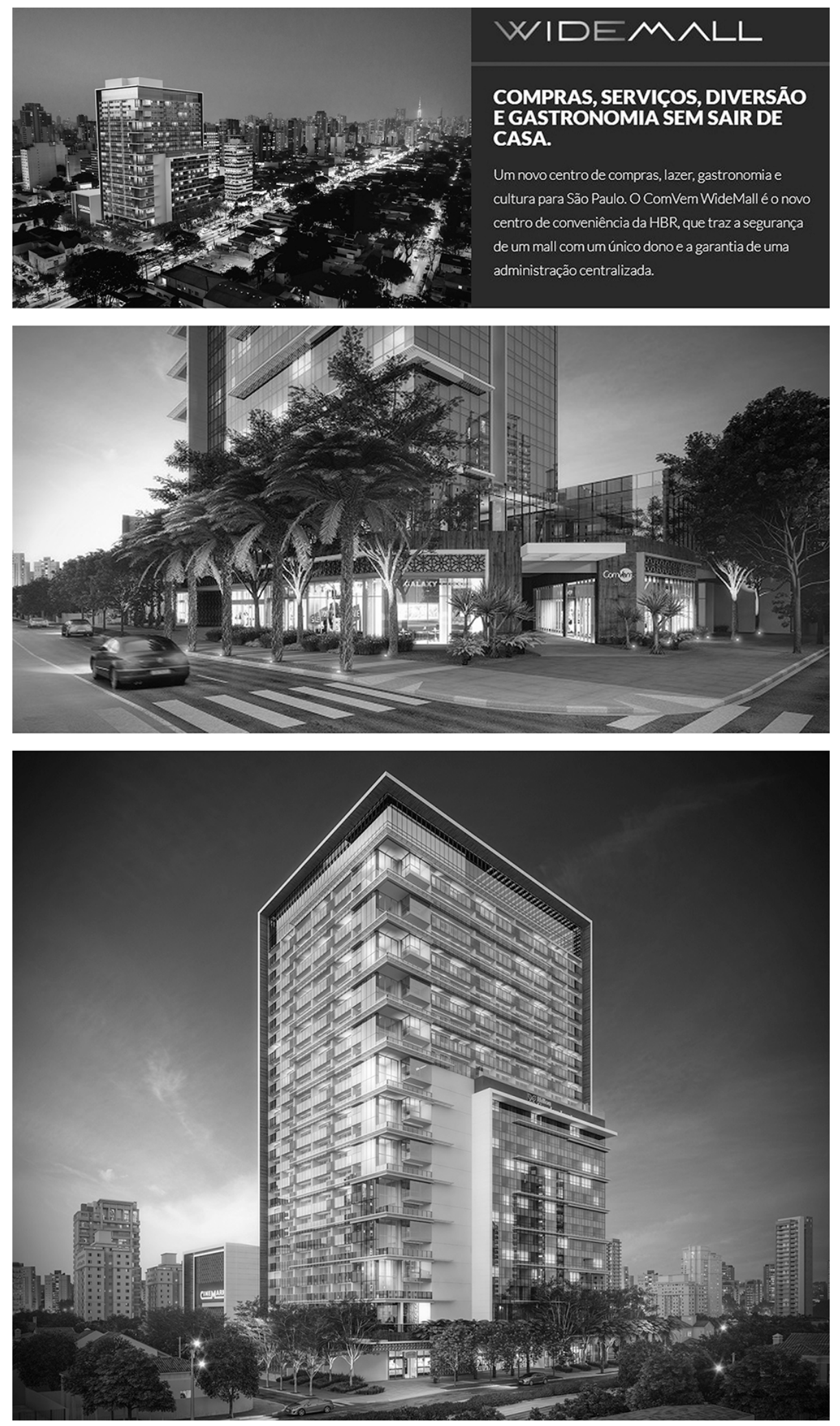

Figura 7. Fachada ativa do Edifício Helbor Wide São Paulo. Avenida Rebouças, 2636 Pinheiros - São Paulo - SP

Fonte: Helbor Wide São Paulo ([s.d.] online). 
Dos encaminhamentos legislativos, deve-se reconhecer o deferimento de artigos da LPUOS de 2016, os quais, referindo-se ou não à fachada ativa, contribuem para uma possível composição morfológica e para a contestação de grandes empreendimentos deletérios ao espaço público. São eles: o Art. 69 (permitindo o alinhamento de testadas em faces de quadra cuja ocupação existente apresente mais de 50\% com essa característica); as diretrizes do Art. 66 (a saber, isenção de recuos laterais e de fundo para empreendimento com até $10 \mathrm{~m}$ de altura, ou para lotes com área de até $250 \mathrm{~m}^{2}$ com declividade, ou com dimensão frontal inferior a $10 \mathrm{~m}$ ); e o Art. 87 (compulsoriedade de fachada ativa para no mínimo $25 \%$ da testada do lote em empreendimentos com área entre $10.000 \mathrm{~m}^{2} \mathrm{e} 20.000 \mathrm{~m}^{2}$ ).

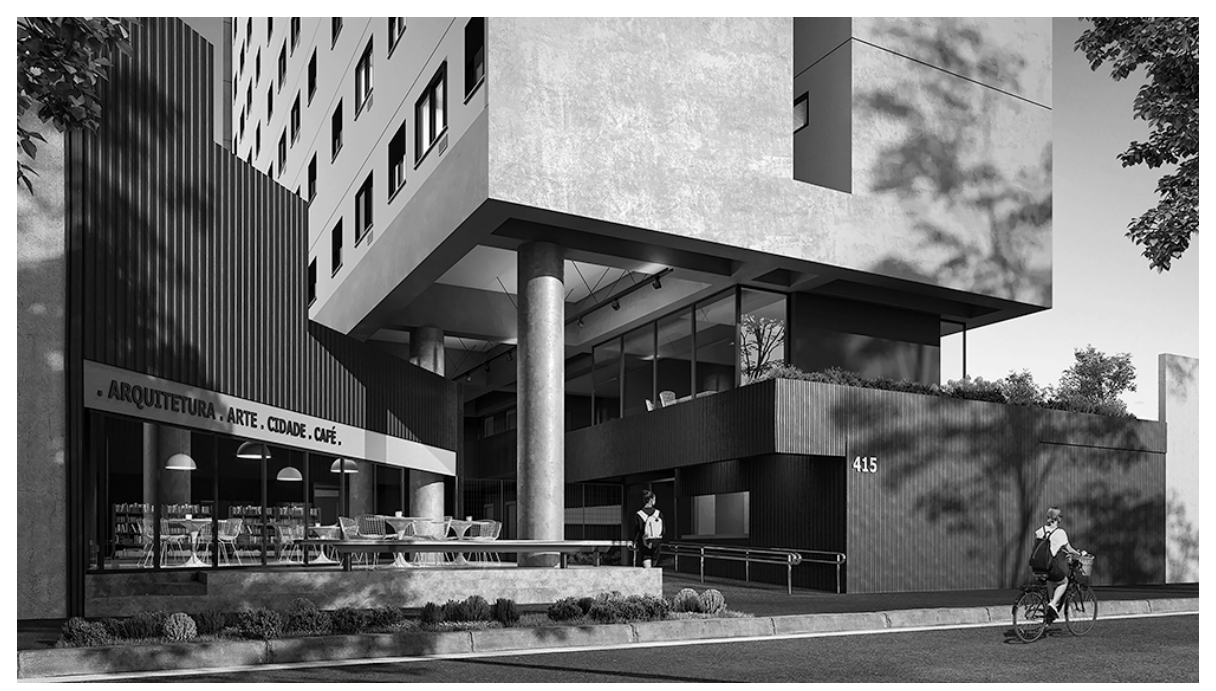

Figura 8. Fachada ativa do Edifício Bem Viver General Jardim. Bem Viver General Jardim. Rua General Jardim, 415 - Vila Buarque - São Paulo - SP. Fonte: Magik ([s.d.] online).

Com base nos objetivos de visão da cidade, presentes no Art. 27 do PDE de 2014 -“[...] proporcionar a composição de conjuntos urbanos que superem exclusivamente o lote como unidade de referência da configuração urbana, sendo também adotada a quadra como referência de composição do sistema edificado" -, pergunta-se: como a legislação direciona a ação do mercado para que a quadra seja uma referência morfológica?

Em um tecido urbano tão complexo como o do município de São Paulo, marcado por um panorama em que, nos últimos cinquenta anos, se compreendeu como usual uma morfologia urbana deletéria à heterogeneidade e à integração, de que modo a lei, cujo foco recai sobretudo no adensamento construtivo e populacional, induz os novos empreendimentos a qualificar o espaço público junto às frentes dos lotes na tentativa de estimular a diversidade de usos e a qualificação dos espaços públicos? 


\section{LEI DE EVENTOS}

RECULAVEITACX DE UM NUMERO MIRUMO DE EVEITOS UREAUDOS POR FRETTE DE RUA COM VAUDADE EA TOOAS AS ZCMLAS MSTAS E ZOMLAS RESIDEIICLAS.

EVEUTOS UREANOS SLO TOCOS OS ACONTECAMEUTOS HO PLANO DE CONTATO BITRE O PRVADO (EDIF)CIOI E O PUEUCO ICALCADA / RUAN: ACESSO A EDEFCIOG, ACESSO A ESPACOS UVRES, PASSAOEIS.

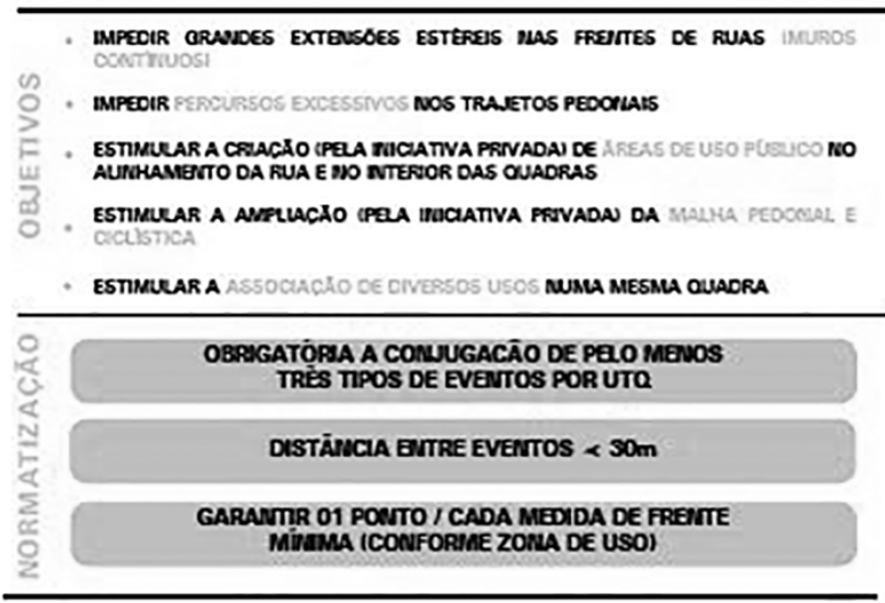

EVENTOS POUCO DINAMICOS

(TPONTOT

ACESSO A EDIRCACOES DE USO PARTICULAR RESIDBVCLN

( $<6$ UTUDADES)

ACESSO A ESTACIORLAMEITOS OU CARCA E DESCARCA, IIDERUIDGUTE DO NUNERO DE VEKCULOS

EVENTOS DINAMICOS [3 PONTOS]

ACESSO A EOIFICACOES DE USO PARTCULAR RESIDEICIAL

1) 6 UHIOADES:

ACESSO A ESTABELECMEITO COMERCIAL

IUMA UNDADO

ACESSO A EOUFICACOES DE ESCATTOROS

[EMTPRESARAAS / TUSTMUCICNANS:

DISTALACAO DE UM ECICLETARIO PARA

Mitrmo 10 eicicletas

EVENTOS MUITO DINAMMICOS

\section{[S PONTO5)}

ACESSO A EOFICACOES DE USO RESIOGTCIAL

[HAETTACAO DE ETTERESSE SOCLNL HISI

ACESSO A EQUPANUETTOS LESCOLA CRECHE.

TREUTLAL CLUEE, TERUILAL, HOSPTAL, POSTO ETC.J

ACESSO A QALENA COMERCIAL

(CADA ACESSO)

ACESSO A ESPACOS DE USO PUELICO

MO MMOLO QUE QUADRA

ESTAEGLCIMEGTO DE TRAVESSIA OU PASSAOEM PUEACA PELO TUTEROR

Figura 9. Quadro explicativo sobre a Lei de Eventos.

Fonte: Noto (2017, p. 280). 
Compreende-se que há uma multiplicidade de ocupações urbanas que devem ser cuidadosamente analisadas, mas é fundamental que flexibilidades da legislação sejam propostas de maneira a levar em consideração cenários diversos, a fim de manter morfologias que contribuam para a segregação socioespacial.

Para tanto, seria necessário estabelecer estratégias mais enfáticas de desenho urbano, como obrigatoriedade de fachada ativa para algumas localidades, mesmo em empreendimentos cujo lote tenha área inferior a $10.000 \mathrm{~m}^{2}$; estipular alargamentos de passeio público, em novos empreendimentos e em determinadas zonas, desejáveis sem recuos frontais, independentemente do uso; e apresentar normativas mais impositivas em relação a elementos que de fato qualifiquem a interface do lote com o passeio público.

Embora os incentivos à fachada ativa suscitem a contestação de empreendimentos monofuncionais isolados no lote, é fato que a legislação urbanística regulada até o momento - seja pelo prazo restrito de configuração das leis, seja pelas suas escalas de trato com a produção da cidade, seja ainda por conta da inexistência de leis de ordenamento da paisagem - é incapaz de superar as limitações individuais do lote, na qual decisões fundamentais de desenho urbano se apresentam como facultativas.

\section{Considerações finais}

Considerada uma importante estratégia de política urbana, a "fachada ativa” contrapõe-se à setorização de usos e tem como propósito qualificar a interface do lote com o passeio público por meio de usos não residenciais no térreo, instalados próximo ou no limite do lote, sem planos fechados, de modo a permitir a permeabilidade visual e acesso irrestrito e fisicamente integrado aos espaços coletivos da cidade.

Se, por um lado, as virtualidades da "fachada ativa” são concordantes ao projeto de cidade preconizado pelo PDE de 2014, por outro, no detalhamento da diretriz, apresentado ao longo da LPUOS de 2016, revelou-se a insuficiência da normativa urbanística como orientação à produção do espaço, cuja potencialidade, já limitada, permite a subversão pelo mercado imobiliário, adaptado, por sua vez, a uma geratriz comum, que nos últimos cinquenta anos, ao menos, produziu amplamente tipos isolados no lote. São edificações rarefeitas, monofuncionais, enclaves ladeados por um extenso muro com poucos acessos, inibindo qualquer possibilidade de apropriação do passeio público e concentrando equipamentos de lazer que enfatizam o ensimesmamento da vida urbana e a segregação socioespacial.

A limitação da normativa em si e também da sua aplicação evidencia-se no descompasso entre objetivo (discurso) e resultado. Transgredindo a lógica da 
função social da propriedade, em que o direito a ela é associado a uma função social, a legislação que incide sobre a morfologia urbana, como advoga Noto, deveria "[...] ser entendida não como um entrave à liberdade projetual, mas como manifestação do interesse coletivo” (NOTO, 2017, p. 352). Aqui, seria possível não só compreender as "fachadas ativas", como igualmente expandir o dever de qualificação do espaço público aos diversos usos que compõem a cidade, dentro, é claro, de suas delimitações.

No decurso deste artigo, buscou-se compreender em que medida a forma do objeto arquitetônico, condicionada pelos parâmetros legais posteriores ao PDE de 2014, em especial pela "fachada ativa", pode ser vista ou não como um avanço do ponto de vista de uma cidade heterogênea e não segregadora, dado o reconhecimento de que o PDE de 2014 e a LPUOS de 2016 implementaram instrumentos qualificadores de ocupação do solo considerados formatadores de um novo paradigma na produção espacial da cidade.

Defrontando esse questionamento, pode-se dizer que reverter o desequilíbrio entre os lugares residenciais e de trabalho, e equilibrar melhor o adensamento populacional e construtivo, com multiplicidade de usos e funções, sobretudo ao longo dos eixos de transporte coletivo, contribuirá, decerto, para a melhoria da vida urbana. Contudo, a estratégia "fachada ativa” não deve ser vista como um fim em si mesma, pois, ainda que implementada de modo a qualificar o espaço público, como estratégia unitária é insuficiente para democratizar a ocupação do espaço urbano.

Um projeto de cidade capaz de agir sobre a segregação socioespacial deve considerar uma relação sistêmica entre um compêndio de instrumentos que possibilitem, além do acesso à terra, a apropriação das mais diversas funções da cidade, dentro da compreensão dialética do espaço como produto e produtor das relações sociais.

Por certo ainda não houve êxito no enfrentamento do impasse disciplinar entre arquitetura e urbanismo, em que haja normativas de desenho urbano capazes de superar a individualidade do lote, contribuindo para a qualificação do espaço público e sua apropriação coletiva. Todavia, em meio a progressos e retrocessos, tal crítica só subsiste porque nas últimas décadas tem havido uma mudança de reivindicações por parte da população que vive na cidade, advindas de uma compreensão de direito à cidade diferente da formulada nos anos 1980 e 1990. No livro A reforma urbana no Plano Diretor Estratégico de São Paulo de 2002-2014, Nabil Bonduki (2018, p. 248) afirma: 
[...] novos temas estão entrando em pauta, além da tradicional agenda da reforma urbana construída no Brasil nos anos 1980 e 1990, no âmbito da luta por direitos mínimos de cidadania. Se para os trabalhadores que migraram do campo entre 1940 e 1990 o acesso à terra, casa própria, infraestrutura (transporte coletivo, água, luz, iluminação pública e coleta de lixo) e serviços sociais (educação fundamental, atendimento básico de saúde, seguridade social), mesmo precário, já significava um avanço significativo em relação ao completo abandono e exploração que viviam no campo, isso se tornou insuficiente para as novas gerações. O desafio é imenso porque, apesar dos avanços, o país chegou ao século XXI sem ter conseguido responder integralmente a essa agenda básica do direito à cidade (que continua sendo necessária), mas, simultaneamente, passou a ser cobrado por uma segunda pauta (BONDUKI, 2018, p. 248).

A construção da agenda urbana atual passa pela ampliação do significado do direito à cidade e pelo questionamento do antigo modelo de desenvolvimento, que se baseava em elementos como a cultura do automóvel e a privatização do espaço viário por ele gerada; a cidade segregada; a mercantilização dos serviços urbanos; a ideologia de segurança; o desprezo pelo espaço público e pelo meio ambiente; a rejeição ao compartilhamento de bens, espaços e serviços urbanos; a cultura do desperdício; a intolerância às minorias e aos diferentes (BONDUKI, 2018, p. 249).

As pautas manifestadas por essa nova geração já estavam muito presentes nas legislações ao longo da década de 2010 e serviram de base para a formulação do novo modelo de cidade objetivado pelo PDE de 2014. Dentre a multiplicidade de reivindicações - o cuidado com o meio ambiente (agroecologia e agricultura urbana; preservação da memória e do patrimônio arquitetônico), a defesa do transporte coletivo e da mobilidade ativa (não motorizada), o fomento à pluralidade cultural, a defesa de igualdades e liberdades fundamentais (étnicas, de gênero, sexual, religiosa) -, destaca-se o respeito à diversidade, à sociabilidade, fundamentado no compartilhamento, na reapropriação e na gestão do espaço público negado nas décadas passadas (BONDUKI, 2018, p. 249-252).

Essas mudanças de perspectiva, que resultaram na consolidação de artigos inseridos na Constituição Federal de 1988 e de legislações urbanísticas posteriores, sustentam a afirmação de Maricato (2000, p. 34) de que a inversão do paradigma urbano não é possível sem reverter a compreensão das relações sociais. Ou seja, resultantes de diversas disputas ideológicas, os PDEs e as LPUOSs, tanto dos anos 2000 como de 2010, representam nas legislações e no espaço as mais diversas concepções dos diferentes segmentos sociais ${ }^{35}$.

35. Tais embates são apresentados no texto "O processo participativo como instrumento de construção pactuada do Plano Diretor” (BONDUKI; ROSSETTO, 2018, p. 192-230). 
Apesar de as legislações urbanísticas, desde a Constituição Federal de 1988, apontarem avanços possíveis, ainda são insuficientes tanto no campo da morfologia urbana como nas demais questões que envolvem "[...] dar conta dos problemas gerados pela urbanização acelerada na segunda metade do século passado, assim como para responder às novas demandas do século XXI, vindas de uma sociedade que há cinco décadas é predominantemente urbana e apresenta novas expectativas” (BONDUKI, 2018, p. 247).

É fundamental não desconsiderar os avanços obtidos até o momento, mas, ainda assim, é preciso atentar para toda a problemática, historicamente existente em nossa sociedade, cuja segregação ideológica se materializa de maneira categórica na produção e na reprodução do espaço urbano. Como afirmam Bonduki e Rossetto (2018), na atual conjuntura, desconceituar os limitados avanços seria enfatizar a segregação estrutural, o esfacelamento das políticas públicas e dos direitos civis vividos no país.

\section{Referências}

ANTENOR, N. M. T. Parcelamento e edificação compulsórios e desapropriação - sanção. In: MOREIRA, M. (coord.). Estatuto da Cidade. São Paulo: Fundação Prefeito Faria Lima: Cepam, 2001. p. 203-225.

BONDUKI, N. O modelo de desenvolvimento urbano de São Paulo precisa ser revertido. Estudos Avançados, São Paulo, v. 71, n. 25, p. 23-36, mar. 2011. Disponível em: http://dx.doi. org/10.1590/S0103-40142011000100003. Acesso em: jan. 2017.

. À guisa de conclusão: os desafios do Brasil urbano no século XXI. In: BONDUKI, N. (org.). A luta pela reforma urbana no Brasil: do Seminário de Habitação e Reforma Urbana ao Plano Diretor de São Paulo. São Paulo: Instituto Casa da Cidade, 2018. p. 246-254.

BONDUKI, N.; ROSSETTO, R. A reforma urbana no Plano Diretor Estratégico de São Paulo de 2002-2014. In: BONDUKI, N. (org.). A luta pela reforma urbana no Brasil: do Seminário de Habitação e Reforma Urbana ao Plano Diretor de São Paulo. São Paulo: Instituto Casa da Cidade, 2018. p. 179-245.

BRASIL. Estatuto da Cidade: Lei Federal $n^{0}$ 10.257, de 10 de julho de 2001. Regulamenta os arts. 182 e 183 da Constituição Federal, estabelece diretrizes gerais da política urbana e dá outras providências. Diário Oficial da União: Brasília, DF: Congresso Nacional, 11 jul. 2001.

CALDEIRA, T. Cidade de muros: crime, segregação e cidadania em São Paulo. São Paulo: EDUSP, 1997.

CARVALHO, J. P. A tipologia dos edifícios de apartamentos e sua relação com o tecido urbano da cidade: um estudo de suas transformações nos últimos 40 anos. 2008. Dissertação (Mestrado) - Faculdade de Arquitetura e Urbanismo da Universidade de São Paulo, São Paulo, 2008. 
CHUVA, M. Fundando a nação: a representação de um Brasil barroco, moderno e civilizado. Topoi, v. 4, n. 7, p. 313-333, jul.-dez. 2003.

ESTADÃO. Uso misto e fachada ativa marcam lançamentos em São Paulo. Novos projetos adotam diretrizes do novo Plano Diretor, 4 anos após a sua aprovação. Estadão, São Paulo, 5. ago. 2018. Disponível em: https://economia.estadao.com.br/blogs/radar-imobiliario/uso-misto-e-fachada-ativa--marcam-lancamentos-em-sao-paulo/. Acesso em: 28 nov. 2019.

FELDMAN, S. Planejamento e zoneamento: São Paulo 1947-1972. São Paulo: EDUSP, 2005.

FERREIRA, J. S. W.; MARICATO, E. Estatuto da Cidade: essa lei vai pegar? Correio da Cidadania, n. 252, jul. 2001. Disponível em: http://www.fau.usp.br/depprojeto/labhab/biblioteca/textos/ferreira_estatuto.pdf. Acesso em: jan. 2017.

GUERRA, M. M. L. G. Aspectos jurídicos do uso do solo urbano. Fortaleza: Editora da Universidade Federal do Ceará, 1981.

HELBOR WIDE SÃO PAULO. Helbor e MPD apresentam: uma nova forma de viver. Uma nova proposta que conecta, em um só endereço, moradia, arte, gastronomia, compras e diversão. [S.n.; s.l.; s.d.]. Disponível em: https://www.helbor.com.br/imoveis/helbor-wide-sp. Acesso em: 27 jun. 2017.

KRAFTA, R. Desenho urbano e regulamentação urbanística. In: BENAMY, T.; MALTA, M. (ed.). SEDUR. SEMINÁRIO SOBRE DESENHO URBANO NO BRASIL. 2., São Paulo. Anais [...]. São Paulo: Pini, 1986. p. 19-25.

LEFEBVRE, H. O direito à cidade. Tradução: Rubens Frias. São Paulo: Centauro, 2001.

MAGIK. Bem Viver General Jardim. [S.n.; s.l.; s.d.]. Disponível em: https://magikjc.com.br/ empreendimento/bem-viver-general-jardim/. Acesso em: 27 jun. 2017.

MARICATO, E. Planejamento urbano no Brasil: as ideias fora do lugar e o lugar fora das ideias. São Paulo: FAU-USP, 2000.

MEYER, R.; CUNHA JR., J.; FONTENELE, S. Centro Novo de São Paulo: um projeto de chão. Vitruvius, out. 2018. Disponível em: https://www.vitruvius.com.br/revistas/read/arquitextos/19.221/7146. Acesso em: 12 dez. 2019.

MIELNIK, R. Dúvidas sobre dados de fachada ativa. São Paulo, 19 nov. 2019.1 (mensagem eletrônica).

MONTANDON, D. T. A implementação do Estatuto da Cidade na escala local: a experiência de São Paulo. In: ROSSBACH, A. (org.). Estatuto da Cidade. A velha e a nova agenda urbana: uma análise de 15 anos de lei. São Paulo: Cities Alliance, 2016.

NAKANO, K.; GUATELLA, S. A. A forma urbana a partir de planos diretores e leis de zoneamento do município de São Paulo. Parc - Pesquisa em Arquitetura e Construção, Campinas, v. 6, n. 3, p. 142-154, set. 2015. ISSN 1980-6809. Disponível em: http://periodicos.sbu. unicamp.br/ojs/index.php/parc/article/view/8640799. Acesso em: 9 dez. 2016. 
NOBRE, E. O ideário urbanístico e a legislação na cidade de São Paulo: do Código de Posturas ao Estatuto da Cidade. In: SEMINÁRIO DE HISTÓRIA DA CIDADE E DO URBANISMO. 9., São Paulo: FAU-USP, EESC-USP, PUC-Campinas, Universidade Presbiteriana Mackenzie, set. 2006. Disponível em: http://www.fau.usp.br/depprojeto/labhab/biblioteca/textos /nobre_ideariourb.pdf. Acesso em: jun. 2016. (Tema. As disciplinas da cidade e o urbanismo).

NOTO, F. S. O quarteirão como suporte da transformação urbana de São Paulo. 2017. Tese (Doutorado) - Faculdade de Arquitetura e Urbanismo da Universidade de São Paulo, São Paulo, 2017.

ANERAI, P.; CASTEX, J.; DEPAULE, J. Formas urbanas: a dissolução da quadra. Tradução: Alexandre Salvaterra. Porto Alegre: Bookman, 2013.

PEREIRA, R. B. Tipologia arquitetônica e morfologia urbana: uma abordagem histórica de conceitos e métodos. Vitruvius, jul. 2012. Disponível em: http://www.vitruvius.com.br/ revistas/read/arquitextos/13.146/4421. Acesso em: 27 jun. 2017.

PORTZAMPARC, C. A terceira era da cidade. Revista Óculum, Campinas, n. 9, 1997.

RIBEIRO, B. A. Entrevista com Benjamin Adiron Ribeiro. Vitruvius, maio 2015. Entrevista concedida a Jorge Pessoa para sua dissertação de mestrado em 2008. Disponível em: http://www.vitruvius.com.br/revistas/read/entrevista /16.062/5523?page=3. Acesso em: 22 maio 2017.

ROLNIK, R. AUP 5895 - Regulação urbanística, configuração sociopolítica em cidades brasileiras e latino-americanas, 2015. Disponível em: http://www.fau.usp.br/cursos/graduacao/arq_urbanismo/disciplinas/aup0535/Aulas/Aula_zoning_nacional_sp_0609.pdf. Acesso em: 24 fev. 2019.

ROLNIK, R.; KOWARICK, L.; SOMEKH, N. (org.). São Paulo: crise e mudança. São Paulo: Brasiliense, 1991.

ROSSBACH, A. Introdução. In: ROSSBACH, A. (org.). Estatuto da Cidade. A velha e a nova agenda urbana: uma análise de 15 anos de lei. São Paulo: Cities Alliance, 2016.

SÃO PAULO (Município). Ato n 663, de 10 de agosto de 1934: Aprova consolidação do Código de Obras Arthur Saboya, (Lei ${ }^{\circ}$ 3.427, de 19 de novembro de 1929) abrangendo todas as disposições constantes de Leis e Atos, em vigor nesta data, referentes a construções, arruamentos, etc. São Paulo: Prefeitura do Município de São Paulo, 1934.

Lei $n^{\circ}$ 7.688, de 30 de dezembro de 1971: Dispõe sobre a instituição do Plano Diretor de Desenvolvimento Integrado do Município de São Paulo - PDDI-SP, e dá outras providências. Diário Oficial da Cidade de São Paulo. São Paulo: Prefeitura do Município de São Paulo, 1971.

Lei $\mathrm{n}^{\circ} 7.805$, de 1 de novembro de 1972. Dispõe sobre o Parcelamento, Uso e Ocupação do solo do município, e dá outras providências. Diário Oficial da Cidade de São Paulo. São Paulo: Prefeitura do Município de São Paulo, 1972. 
SÃO PAULO (Município). Lei no 11.228 de 25 de junho de 1992: Dispões sobre as regras gerais e específicas a serem obedecidas no projeto, licenciamento, execução, manutenção e utilização de obras e edificações, dentro dos limites dos imóveis, revoga a Lei n 8266 , de 20 de junho de 1975, com as alterações adotadas por leis posteriores, e dá outras providências. Diário Oficial da Cidade de São Paulo. São Paulo: Prefeitura do Município de São Paulo, 1992.

Lei ${ }^{0} 13.430$ de 13 de setembro de 2002: Institui o Plano Diretor Estratégico e o Sistema de Planejamento e Gestão do Desenvolvimento Urbano do Município de São Paulo. Diário Oficial da Cidade de São Paulo. São Paulo: Prefeitura do Município de São Paulo, 2002.

Lei $\mathrm{n}^{0} 13.885$ de 25 de agosto de 2004: Estabelece normas complementares ao Plano Diretor Estratégico, institui os Planos Regionais Estratégicos das Subprefeituras, dispõe sobre o parcelamento, disciplina e ordena o Uso e Ocupação do Solo do Município de São Paulo. Diário Oficial da Cidade de São Paulo. São Paulo: Prefeitura do Município de São Paulo, 2004.

Lei $\mathrm{n}^{\circ} 16.050$ de 30 de junho de 2014: Institui o Plano Diretor Estratégico e o Sistema de Planejamento e Gestão do Desenvolvimento Urbano do Município de São Paulo. Diário Oficial da Cidade de São Paulo. São Paulo: Prefeitura do Município de São Paulo, 2014.

Lei $\mathrm{n}^{0} 16.402$ de 22 de março de 2016: Estabelece normas complementares ao Plano Diretor Estratégico, institui os Planos Regionais Estratégicos das Subprefeituras, dispõe sobre o parcelamento, disciplina e ordena o Uso e Ocupação do Solo do Município de São Paulo. Diário Oficial da Cidade de São Paulo. São Paulo: Prefeitura do Município de São Paulo, 2016.

SÃO PAULO (Município); IAB-SP (org.). Concurso Nacional Ensaios Urbanos: Desenhos para o Zoneamento de São Paulo. São Paulo: Prefeitura do Município de São Paulo, 2013. Disponível em: https://www.iabsp.org.br/?concursos=concurso-nacional-ensaios-urbanos-desenhos-para-o-zoneamento-de-sao-paulo-2. Acesso em: 22 maio 2017.

WISNIK, G. Modernidade congênita. In: ANDREOLI, E.; FORTY, A. (org). Arquitetura moderna brasileira. London: Phaidon, 2004. p. 22-55.

ZEIN, R. V. A arquitetura da Escola Paulista Brutalista (1953-1973). 2005. Tese (Doutorado) Programa de Pesquisa e Pós-graduação em Arquitetura da Universidade Federal do Rio Grande do Sul, Porto Alegre, 2005. 


\section{Tatiane Oliveira Teles}

Graduada em 2015 pela Faculdade de Arquitetura e Urbanismo da Universidade de São Paulo (FAU-USP). Contemplada com menção honrosa no concurso para estudantes da IX Bienal Iberoamericana de Arquitetura e Urbanismo de Rosário, Argentina, em 2014. Contemplada com intercâmbio estudantil no exterior com bolsa do Governo Federal, de 2012 a 2013, na Faculty of Engineering Science, Kuleuven, Bélgica. Mestre pela FAU-USP, com pesquisa intitulada "Legislação urbanística e forma urbana. São Paulo, século XXI", com bolsa aprovada pela Fapesp. Pesquisadora junto ao projeto temático "Arquitetura e urbanismo frente ao espaço social no século 21", vinculado ao grupo de pesquisa Pensamento Crítico e Cidade Contemporânea (PC3).

Email: tatiane.teles@usp.br

ORCID: 0000-0003-4341-6666

Submissão: 6 de junho de 2020.

Aprovação: 19 de outubro de 2020.

Como citar: TELES, T. O. Legislação urbanística e forma urbana. São Paulo no século XXI. Revista brasileira de estudos urbanos e regionais. v. 22, e202042, 2020. DOI 10.22296/2317-1529.rbeur.202042.

Artigo licenciado sob Licença Creative Commons CC BY 4.0. https://creativecommons.org/licenses/by/4.o/deed.pt_BR 